Board of Governors of the Federal Reserve System

International Finance Discussion Papers

Number 1101

March 2014

\title{
Evaluating Asset-Market Effects of Unconventional Monetary Policy: A Cross-Country Comparison
}

\author{
John H. Rogers \\ Federal Reserve Board \\ Chiara Scotti \\ Federal Reserve Board \\ Jonathan H. Wright \\ Johns Hopkins
}

NOTE: International Finance Discussion Papers are preliminary materials circulated to stimulate discussion and critical comment. References in publications to International Finance Discussion Papers (other than an acknowledgment that the writer has had access to unpublished material) should be cleared with the author or authors. Recent IFDPs are available on the Web at www.federalreserve.gov/pubs/ifdp/. This paper can be downloaded without charge from Social Science Research Network electronic library at http://www.ssrn.com/. 


\title{
Evaluating Asset-Market Effects of Unconventional Monetary Policy: A Cross-Country Comparison*
}

\author{
John H. Rogers ${ }^{\dagger} \quad$ Chiara Scotti $^{\ddagger} \quad$ Jonathan H. Wright ${ }^{\S}$
}

March 7, 2014

\begin{abstract}
This paper examines the effects of unconventional monetary policy by the Federal Reserve, Bank of England, European Central Bank and Bank of Japan on bond yields, stock prices and exchange rates. We use common methodologies for the four central banks, with daily and intradaily asset price data. We emphasize the use of intradaily data to identify the causal effect of monetary policy surprises. We find that these policies are effective in easing financial conditions when policy rates are stuck at the zero lower bound, apparently largely by reducing term premia.
\end{abstract}

JEL Classification: C22, E43, E48

Keywords: Large scale asset purchases, quantitative easing, zero bound, term premium.

${ }^{*}$ We are grateful to David Bowman, Chris Erceg, Joseph Gagnon, Philip Lane, David LópezSalido, Edward Nelson, Charlie Thomas, Beth-Anne Wilson, Egon Zakrajsek and two anonymous referees for helpful comments. We thank Rebecca DeSimone and Eric English for outstanding research assistance. All errors are ours alone. The views expressed in this paper are solely the responsibility of the authors and should not be interpreted as reflecting the views of the Board of Governors of the Federal Reserve System or of any other person associated with the Federal Reserve System.

${ }^{\dagger}$ International Finance Division, Federal Reserve Board, Washington DC 20551; john.h.rogers@frb.gov.

${ }_{\ddagger}^{\ddagger}$ International Finance Division, Federal Reserve Board, Washington DC 20551; chiara.scotti@frb.gov.

${ }^{\S}$ Department of Economics, Johns Hopkins University, Baltimore MD 21218; wrightj@jhu.edu. 


\section{Introduction}

Over recent years, short-term nominal interest rates in many countries have effectively been driven to the zero lower bound. ${ }^{1}$ Deprived of their traditional tool for policy, the four major central banks have begun adopting unconventional monetary policy, including forward rate guidance, asset purchases and programs to directly support bank lending. These unconventional policies differ across central banks, but have many points in common (Lenza et al., 2010).

Unfortunately, measuring the effects of monetary policy on other asset prices in this environment poses special challenges. In normal times, the lumpy manner in which monetary policy news is released to the public is a powerful source of identification. One can define a monetary policy surprise as the difference between the central bank's announcement concerning the short-term interest rate and the ex-ante expectation of this announcement, measured from interest rate futures quotes (Kuttner, 2001). And then one can study how other asset prices respond to monetary policy news, probably safe in the assumption that in a short window around the announcement, this news is the only driver of asset prices. But with unconventional policy, there is no clear measure of the central bank's policy stance, and no easy way to determine policy expectations. Thus, the simple event-study methodology breaks down.

But even in the era of unconventional policy, news still comes out in a lumpy manner. The news is just harder to measure. A number of approaches have been used to attempt to adapt the conventional event-study approach to examine the effects of monetary policy surprises in this new environment. Some authors, such as Doh

\footnotetext{
${ }^{1}$ When we talk about the zero lower bound, we don't mean that short-term interest rates are necessarily driven precisely to zero. For institutional and technical reasons, most central banks have kept short rates a little above zero. Still, for all practical purposes, the US, UK, euro area and Japan are all effectively at the zero lower bound.
} 
(2010), Gagnon et al. (2011), Meaning and Zhu (2011), Neely (2010), Krishnamurthy and Vissing-Jorgenson (2011), Joyce and Tong (2012) and Swanson (2011), have identified announcements that they argue are complete surprises, and then simply added up the jumps in asset prices in short windows bracketing these announcements. ${ }^{2}$ This strategy hinges on the entire announcement being unexpected, as was arguably the case for some important announcements by the Federal Reserve (Fed) and the Bank of England (BOE) in 2008 and 2009. But most monetary policy announcements have been at least in part anticipated, with news coming out in a gradual manner before the announcement.

Another approach, considered by Cahill et al. (2013) and Joyce et al. (2011), is to estimate the effects of the surprise component of asset purchase announcements, using survey expectations to measure these surprises. However, surveys have limited data availability (both in terms of sample period and questions asked) and are not necessarily perfect measures of investors' beliefs. ${ }^{3}$

We take a different approach in this paper, which is however limited to measuring the relative effects of monetary policy on different asset prices. We define the monetary policy surprise as the intraday change in government bond yields right around the announcement, and then regress other asset returns around the announcement on this measure of the monetary policy surprise. There are two important caveats to this methodology. First, it only measures the pass-through from a given change in government bond yields (caused by monetary policy) onto other asset prices, not the efficacy of monetary policy in affecting government bond yields. But this is still

\footnotetext{
${ }^{2}$ Some researchers examine the effects of central bank purchases of specific securities as opposed to announcements, for example Ghysels et al. (2012) for the ECB Securities Market Program, D'Amico and King (2013) for the US, or Meaning and Zhu (2011) for the US and UK. We are however focusing on monetary policy announcements.

${ }^{3}$ For example, the announcement at the June 2013 FOMC meeting about the timeline for ending asset purchases was not far from survey expectations and yet roiled global fixed income markets.
} 
an important question, as several researchers have questioned the ability of declines in sovereign bond yields to be transmitted into other asset prices (Eggertsson and Woodford, 2003; Krishnamurthy and Vissing-Jorgenson, 2013). Second, it measures the composite effects of monetary policy on asset prices, without decomposing it into the effects of specific policies, such as forward guidance or asset purchases. It is difficult to separate the effects of these different types of unconventional policy, since many announcements covered policies of multiple types. But we do also make an attempt to separate out the effects of different types of unconventional monetary policy announcements. We also attempt to estimate the persistence of announcement effects - an important, but particularly difficult task.

Especially in the current environment, the event study methodology is of far more than academic interest. Policymakers have seen the immediate effects of news announcements on asset prices, and we strongly suspect that this has in turn helped to persuade them of the benefits of some unconventional monetary policies. This is perhaps particularly true for the European Central Bank (ECB).

In this paper, we focus on using intradaily data where possible. The use of intradaily data is potentially helpful to zero in on the window where monetary policy is the only information coming out (Faust et al., 2007; Gürkaynak and Wright, 2013). However, in the current environment, announcements are complicated, and take time to digest, and are often explained in subsequent press conferences. Consequently, the assumption that the monetary policy surprise can be directly measured from the jumps in government bond yields in an intradaily window around the announcement time may be questionable. Too narrow a window will miss part of the monetary policy news, but yet too wide a window will contaminate the monetary policy news with other shocks. Mindful of this concern, we also consider another closely-related approach, which is identification through heteroskedasticity, employing the method- 
ology of Rigobon and Sack (2003a,b, 2004, 2005). This only requires us to assume that days of monetary policy announcements are days on which the variance of monetary policy shocks was especially high — a much weaker restriction. Papers employing these methods include Gilchrist and Zakrajsek (2013), Raskin (2013), Arai (2013) and Wright (2012).

The literature on using event-study and related methodologies to measure the asset price effects of monetary policy shocks in the era of unconventional monetary policy is large and growing fast. Our paper uses the same general methodologies that are used in existing work. However, our paper has some novel aspects, such as the emphasis on intradaily data. And it conducts the analysis on a consistent basis for the four main advanced-economy central banks: the Fed, the ECB, the BOE and the Bank of Japan (BOJ).

The plan for the remainder of this paper is as follows. Section 2 summarizes country experiences with unconventional monetary policy, updating the narrative of Lenza et al. (2010). Section 3 proposes intraday measures of monetary policy surprises and examines their effects on other asset prices. Section 4 embeds this identification of monetary policy shocks in a structural VAR, to estimate the persistence of effects. Section 5 considers the strategy of identification through heteroskedasticity. Section 6 contains some discussion of policy implications. Section 7 concludes.

\section{Country Experiences with Unconventional Policy}

\section{$2.1 \quad$ United States}

In the United States, by late 2008 the Federal Open Market Committee (FOMC) had brought the federal funds rate close to zero - effectively, its lower bound. With the 
traditional tool for expansionary monetary policy thus sidelined, the FOMC turned to unconventional policy options: "forward guidance" about future policy and large-scale asset purchases (LSAPs). Forward guidance began with simple and general remarks in the FOMC statements: "economic conditions are likely to warrant exceptionally low levels of the federal funds rate for an extended period." This was enhanced in August 2011, when the Committee specified "at least through mid-2013" in place of "an extended period." The projected end date was pushed into the future several times, and in September 2012 it was shifted to mid-2015. Forward guidance was further enhanced with efforts to provide clarity about the economic conditions that would lead to an unwinding of the unconventional stimulus policies. In January 2012, the FOMC released a statement specifying its longer-run goals on inflation (2 percent) and the "normal" rate of unemployment (5.2-6 percent). Meanwhile, the Committee clarified how it would use the federal funds rate to achieve these dual objectives. In December 2012, the Committee replaced its "calendar guidance" with a statement anticipating that exceptionally low levels for the federal funds rate will be appropriate "at least as long as the unemployment rate remains above $61 / 2$ percent, inflation between one and two years ahead is projected to be no more than a half percentage point above the Committee's 2 percent longer-run goal, and longer-term inflation expectations continue to be well anchored."

The FOMC has also authorized a series of large scale asset purchases (LSAPs) of longer term securities. Starting in late 2008, the Fed has purchased longer-term government agency debt securities and mortgage-backed securities (MBS), and longerterm Treasury securities. These purchase, which were intended to lower longer-term interest rates and raise asset prices, added over $\$ 2.5$ trillion to Federal Reserve assets. The first LSAP program, involving agency debt and MBS, was announced in November 2008. The purchase program was later stepped up and broadened to in- 
clude longer term Treasury securities. The first round of LSAPs was completed in March 2010. In November 2010, purchases were again stepped up with reinvestment arrangements, under which the Fed redeployed the principal payments from agency securities into purchases of longer term Treasuries. From then until June 2011, the Fed's second LSAP program (QE2) involved the purchase of $\$ 600$ billion in longer term Treasuries. Since then the FOMC has continued to maintain the level of securities holdings attained under the LSAPs, with further adjustments to its investment policy including a shift towards a longer average maturity for its Treasury portfolio. The two tenets of U.S. monetary policy, forward guidance and LSAPs, are naturally intertwined, thus posing challenges to econometric identification. The effects of asset

purchases depend on expectations of (1) the total value of intended purchases and (2) how long the FOMC intends to hold them. If the Committee buys today but sells tomorrow, there will be little effect on those asset prices. To make LSAPs as effective as possible, the FOMC has attempted to communicate the intended path of holdings years into the future. These communications issues have become the subject of considerable discussion in recent months.

\subsection{United Kingdom}

As part of its response to the global financial crisis and domestic economic downturn, the BOE Monetary Policy Committee (MPC) cut its policy rate from 5 percent in October 2008 to 0.5 percent, its effective lower bound, in March 2009. But the Committee also decided it needed to ease monetary conditions further in March 2009 through a $£ 75$ billion Asset Purchase program (APF) to purchase public sector assets 
with residual maturity of 5-25 years financed by creation of central bank money. ${ }^{4}$ The APF size was gradually increased from $£ 75$ billion to $£ 200$ billion in February of 2010 . Following a pause, the MPC resumed increasing the size of the APF in October 2011, reaching $£ 375$ billion by the end of 2012 . In addition to the $£ 375$ billion financed by reserve issuance, the $\mathrm{BOE}$ is also authorized to purchase up to $£ 10$ billion in private assets financed by Treasury issuance ${ }^{5}$. But at the time of writing, the APF has no such assets. The BOE is indemnified by the UK Treasury against losses on the APF. On August 7 2013, BOE adopted a forward guidance framework with the intent of clarifying its policy reaction function and thus "give confidence to businesses and households that policy will not be tightened until there is material reduction in economic slack" (Charlie Bean, Deputy Governor of BOE for monetary policy). The BOE's forward guidance is conditional on the unemployment rate reaching a threshold of 7 percent.

\subsection{Euro Area}

Following Lehman's collapse, the spread between unsecured interbank deposit rates (EURIBOR) and overnight indexed swap (OIS) rates at the three-month maturity peaked at 200 basis points in the euro area. In response, on October 8, 2008 the ECB cut its key policy rate by 50 basis points, part of a coordinated effort with several major central banks, including the Fed, the BOE and the BOJ. Soon after, the ECB announced several important innovations in its operational procedures. Giannone

\footnotetext{
${ }^{4}$ The UK APF was actually announced in January of 2009 when the UK Treasury authorized the BOE to buy up to $£ 50$ billion of "high quality private assets" to "increase the availability of corporate credit by reducing the illiquidity of the underlying instruments" . Because Treasury would finance these purchases through the sale of short-term gilts, they would not constitute quantitative easing. Real quantitative easing, was introduced in March of 2009 with the announcement of the $£ 75$ billion APF.

${ }^{5}$ This limit on the purchases of private sector assets had been $£ 50$ billion, but was reduced in November 2011, following an exchange of letters between the Governor and the Chancellor.
} 
et al. (2011) discuss the ECB's actions at this time in detail. Starting in 2009, the strains from the Great Recession, and the costs that governments faced to bail out their insolvent banking systems, began to cause euro-area sovereign debt spreads to increase, and eventually led to questions about the sustainability of the single currency area.

The ECB's actions were guided by the limitations placed on it by the Lisbon Treaty which prohibits the Eurosystem from conducting purchases of sovereign debt that are interpreted as sovereign bailouts (Article 125) or monetary financing (Article 123). Asset purchases, the magnitude of which are practically negligible, have been therefore conducted with the objective of addressing market dysfunctions and repairing the transmission mechanism of monetary policy. The ECB introduced the Securities Market Programme (SMP) in May 2010 and the Outright Monetary Transaction (OMT) program in August 2012 to purchase euro-area sovereign debt. Because these programs are sterilized, they technically do not constitute monetary easing. It is noteworthy that the OMT has not been activated so far. The ECB also introduced in 2009 and 2011 two Covered Bond Purchase Programmes (CBPP1 and CBPP2) to buy covered bonds across the Euro Area in both primary and secondary markets.

In addition, the ECB introduced a number of new measures within its regular monetary policy framework. First, the ECB adopted in October 2008 a fixed rate/full allotment (FRFA) tender procedure in its monetary policy operations, which is currently supposed to be maintained till mid-2015. This measure helped to stabilize the banking sector at a time of significant stress by deferring to its counterparties the decision on the quantity of liquidity to be provided. Second, the ECB expanded its list of eligible collateral, for example by reducing the rating threshold for certain securities and by allowing National Central Banks (NCBs) to accept as collateral additional performing credit claims, provided the NCBs retained the credit risk associated with 
such transactions. Third, the ECB increased the number and variety of Eurosystem longer-term refinancing operations (LTROs). In normal times, financial institutions borrow from the Eurosystem through regular open market operations with maturities of 7-days (Main Refinancing Operations, MRO) or 3-months LTROs. Over time, the ECB has introduced special 1-, 6-, 12-, 24- and 36-month operations. In 2009, the ECB conducted three 1-year LTROs, with the first 1-year LTRO eliciting $€ 442$ billion in demand. In October 2011, the ECB reintroduced two 1-year LTROs, but the second operation was replaced by the first 3-year LTRO. On December 2011, in fact, the ECB introduced two 3-year LTROs that elicited an extraordinary demand. Fourth, the ECB decreased the reserve ratio from 2 to 1 percent, effective January 18, 2012, which freed up over $€ 100$ billion.

Since 2008, the ECB has also announced several changes to its target rate, the MRO rate. The rate was cut from 4.25 percent in early October 2008 to 1 percent by May of 2009. Despite a short-lived reversal in 2011 when the MRO rate was increased to 1.5 percent, the ECB has been lowering its target rate over the past two years. The rate reached 25 basis points in November $2013 .^{6}$

\subsection{Japan}

The BOJ has experimented with unconventional policies since the late 1990s and was the first major central bank to introduce a policy of quantitative easing (QEP) as well as forward guidance. QEP was structured in three parts: a commitment to maintain zero interest rates until deflation clearly ended (forward guidance); a significant increase in the Bank's balance sheet; and a change in the composition of that balance sheet by increasing its outright purchases of longer-dated Japanese

\footnotetext{
${ }^{6}$ The ECB only began providing some qualitative forward guidance in July 2013, a substantial change in ECB communication, as both Draghi and his predecessor, Trichet, had stated that the ECB would never pre-commit.
} 
government securities. Overall in Japan, because many important measures were introduced at the same time of the forward guidance, it is difficult to gauge the effectiveness of this commitment. QEP was implemented initially from 2001 to 2006 and then again beginning in 2011 and with Abenomics. The initial foray of the BOJ into quantitative easing policy was from March 2001 to March 2006. Japan faced low economic growth, persistent deflation and a great number of non-performing loans in its banking system left over from the first Asian financial crisis of 1997 and the dotcom bubble that burst in $2000 .^{7}$ Initially, the BOJ increased the outstanding balance of current accounts held at the BOJ from 4 to 5 trillion yen. Its initial outright purchase pace of long-term government bonds was $¥ 400$ billion per month. Over the five years that the program was in place, the BOJ raised its current-account target six times.

In 2006 and 2007 the BOJ allowed short-term bonds to roll-off in preparation for raising rates, but in October of 2010 it announced another Asset Purchase Program (APP). The APP was part of the Comprehensive Monetary Easing together with a "virtually zero interest rate" policy and a commitment to maintain zero interest rates until the BOJ judged that price stability (i.e. 1 percent inflation) was in sight. The APP aimed at reducing term and risk premia through purchases of government securities, corporate bonds, commercial paper, exchange-traded funds (ETFs), and real estate investment trusts (REITs). Its size was initially set at $¥ 35$ trillion, but

\footnotetext{
${ }^{7}$ At the same time QEP provided the banking system with liquidity, the BOJ and Japan's government stepped up programs from the late 1990s designed to remove NPLs from bank balance sheets. The government provided a blanket guarantee on deposits and enabled the Resolution and Collection Corporation (RCC) to purchase non-performing loans and the Industrial Revitalization Corporation of Japan (IRCJ) to purchase loans from those financial institutions that had been deemed to be sound. In addition, in October 2002, the BOJ announced the Stock Purchasing Program in which the Bank purchased stocks held by commercial banks. By the time the program ended in September 2004, the Bank held a total value of $¥ 2$ trillion of equities purchased from Japanese banks. By the summer of 2003 the BOJ was also purchasing asset-backed commercial paper and securities from bank directly.
} 
increased to $¥ 101$ trillion by December 2012. On April 4, 2013, the BOJ announced its Qualitative and Quantitative Easing in which it increased purchases of Japanese government bonds (JGBs) to $¥ 50$ trillion yen a year (from $¥ 20$ trillion in 2012), and

it extended the average maturity from 3 to 7 years. In the same announcement the BOJ committed to increase the monetary base at a pace of $¥ 60$-70 trillion a year over the next two years and it set an explicit two-year time horizon to achieve a 2 percent inflation target.

\section{Immediate Announcement Effects of Monetary Policy News}

For the different central banks, we list the monetary policy announcement days that we consider in Tables 1-4, and we also report the times of these announcements, which are important for our intraday analysis. Most announcements concern unconventional monetary policy initiatives, though there were some changes in short-term policy interest rates over this period. Most announcements consist of statements after policy meetings, but some important speeches and other events are included as well. Our goal is to study the financial market effects of these announcements.

We consider a large number of announcements, most of which were either not very consequential, or largely anticipated. But there are several policy announcements that came as big surprises, which is of course what we want for identification. Four good examples are the BOE and FOMC announcements of Treasury purchase programs in March 2009, the announcement of open-ended asset purchases by the BOJ on April 4, 2013, and the FOMC meeting of June 19, 2013, signalling an earlier-than-expected end to LSAPs. We examine the effects of these announcements on government bond 
yields in the country/currency area for which the announcement was made. Figure 1 plots the change in zero-coupon yields and forward rates of different maturities (the forward rate yield curve) using daily government yield curve data bracketing each of these announcements.

Looking at forward rates is useful, because under the expectations hypothesis of the term structure, these should be equal to expected future short rates. So this can give us an idea of whether a downward shift in the yield curve owes to the central bank effectively committing to keep rates at zero for longer than had been expected, as prescribed by Eggertsson and Woodford (2003), or to falling term premia. A fall in yields that is concentrated in forward rates two or three years hence could potentially be interpreted as either pushing back the expected timing of liftoff from the zero lower bound, or as a drop in the term premia. But a fall in yields that is concentrated in forward rates five years and beyond is only plausibly interpretable as a decline in term premia - a central bank cannot provide credible forward guidance at these horizons. Indeed, any effect of monetary policy accommodation on long-term expectations of future short rates should be for them to go up, as a more accommodative stance of policy raises perceptions of steady-state inflation (Gürkaynak et al., 2005a).

The March 2009 announcement by the BOE and the April 2013 announcement by the BOJ both produced the largest declines in long-term rates, including big drops in forward rates ten to twenty years hence. For these two announcements, it seems clear that the decline in rates owes to a fall in the term premium. The asset purchase program announced by the Fed in 2009 was explicitly limited to bonds in the twoto-ten-year sector and so it is natural that these rates fell the most. But forward rates five-years-ahead and beyond dropped sharply, and again declining term premia seems very likely to be the main explanation. Just to get an idea of scale, the drop in ten-year yields on the day of the March 2009 FOMC meeting was the largest one-day 
absolute change in ten-year yields from 1987 to the time of writing.

The June 2013 FOMC meeting was an example of a surprise going in the opposite direction, and is significant to policy going forward for that very reason. As investors read the announcement and press conference as signaling an earlier-than-expected end to LSAPs, they brought forward their expected timing of the onset of monetary policy tightening and drove term premia higher. The shift in forward rates was a bit more front-loaded than for the other three announcements considered in Figure 1. At the same time, interest rate uncertainty, as measured by options, increased substantially. That seems consistent with a rebound in term premia. A variety of other pieces of monetary policy news in the US around this time, such as Chairman Bernanke's testimony to Congress on May 22, 2013, produced similar effects.

Besides the fact that these announcement produced large shifts in forward rates at the five-year-ahead horizon and beyond, there are two other reasons for thinking that much of these yield curve movements represent shifts in term premia. First, surveys have shown no evidence of long-horizon expectations of future short rates moving much, except that long run inflation expectations have moved up recently in Japan, which makes the presumptive term premium shift in that country even bigger. Second, in these and other episodes, it was the specific securities that the central bank intended to buy whose prices moved the most (see for example D'Amico et al. (2012) and Joyce and Tong (2012)). ${ }^{8}$

\subsection{Pass-through beyond government bond yields}

From these events, we take it as given that central banks are capable of producing meaningful immediate effects on their own government bond yields, that probably

\footnotetext{
${ }^{8}$ Term premia shifts can be further decomposed into duration risk premia and local supply effects, see for example D'Amico et al. (2012) and Cahill et al. (2013).
} 
mainly reflect shifts in term premia. The remainder of the paper seeks to measure the pass-through into other asset prices, and also the persistence of these effects. We can measure monetary policy surprises as intraday changes in government bond yields right around the announcement time. For the US, this is the first principal component of the change in yields for two-, five- and ten- and thirty-year Treasury futures. ${ }^{9}$ For the UK, it is the change in long gilt futures yields. For Japan, it is the change in ten-year JGB futures yields. Given the unique circumstances facing the euro area, we measure ECB monetary policy surprises somewhat differently as intraday changes in cash-market spreads between yields on Italian ten-year government bonds and their German counterparts. More on this in subsection 3.2 below. In all cases, the intraday window is either from 15 minutes before to 15 minutes after (narrow window), or from 15 minutes before to 1 hour 45 minutes after (wide window). All monetary policy surprises are normalized to be of 25 basis point magnitude, and all surprises are signed so that a positive surprise represents an easing of monetary policy - the surprise is minus the relevant yield change.

The idea of measuring monetary policy surprises directly from asset prices was also considered by Gürkaynak et al. (2005b) who used near-term money market futures quotes to measure the effect of monetary policy announcements on expectations of the path of policy during the period of conventional monetary policy. Wright (2012) extended this to using Treasury futures during the recent period of unconventional monetary policy, and the same approach is used in Glick and Leduc (2012). But in this paper we are applying the idea to the announcements from all four central banks.

Having obtained a measure of monetary policy surprises, for each central bank we

\footnotetext{
${ }^{9}$ For all government bond futures, yield changes are approximated by dividing price changes by minus the modified duration of the cheapest-to-deliver security.
} 
consider regressions of the form:

$$
\Delta y_{t}=\beta M P S_{t}+\varepsilon_{t}
$$

where $\Delta y_{t}$ denotes a yield change or asset price returns in a daily or intradaily window bracketing the announcement and $M P S_{t}$ denotes the monetary policy surprise. The financial asset prices consist of intradaily data on bond, stock and exchange rate futures, combined with daily data on corporate bond yields, the MOVE index ${ }^{10}$ and euro-area sovereign yields, as listed in Table 5. The regressions are run without an intercept. Our sample period goes from around the start of the era of unconventional policy through June 2013; the data start in January 2007 for Japan, in August 2007 for the ECB, in November 2008 for the Fed, and in January 2009 for the BOE.

The results using the narrow window to measure both the monetary policy surprises and the intradaily changes on the left hand side of equation (1) are shown in Table 6. The corresponding results using the wide window are reported in Table 7. Here and throughout this paper, we estimate regressions by robust regression to avoid excessive influence of outliers. ${ }^{11}$ In most cases, OLS estimation would give similar results, but there are some parameters where limiting the influence of outliers makes a substantial difference.

Using the narrow window (Table 6), for the Fed, BOE or BOJ, the expansionary monetary policy surprise significantly lowers corporate bond yields, but the fall in corporate bond yields is less than one-for-one. That in turn means that the yield spreads of corporate bonds over their sovereign counterparts widens, but of course what matters for economic activity is the rate, not the spread. Still it is important to be clear that the risk premium which is potentially decreasing is the term premium on

\footnotetext{
${ }^{10}$ The MOVE index is an index of options-implied interest rate volatility.

${ }^{11}$ We use the robust regression M-estimator of Huber (1981) with the bisquare weighting function.
} 
government bonds, ${ }^{12}$ not the risk premium component of the corporate-government bond spread. ${ }^{13}$

The expansionary monetary policy shock significantly raises domestic stock prices in the US and the euro area, but not in the UK or Japan. This is consistent with the existing literature. Rosa (2012) found that UK monetary policy shocks have comparable effects on other fixed income markets to their US counterparts, but have smaller effects on equity markets, and Arai (2013) found a similar result for Japan.

An expansionary monetary policy shock by the Fed, BOE or BOJ causes the domestic currency to depreciate significantly. But for the ECB, the effect goes in the opposite direction. The euro-area expansionary monetary policy surprise leads the euro to appreciate significantly, and also causes German bond and euro-area corporate bond yields to rise significantly, presumably because the surprise lessened safe-haven flows into bunds and promoted financial stability and confidence in the survival of European monetary union. The euro-area expansionary monetary policy surprises causes the pound to appreciate slightly (but significantly) viz-a-viz the dollar and causes Spanish sovereign yields to fall sharply.

Also, we find that monetary policy shocks in one currency area affect bond yields in other currency areas, but the spillovers go mainly from US monetary policy surprises to non-US yields rather than the other way round. For example, the US monetary policy surprise that lowers the ten-year US yield by 25 basis points reduces German and UK ten-year yields by 11 and 10 basis points respectively. The UK monetary

\footnotetext{
${ }^{12}$ Traditionally, we think of this as not embodying any default risk, but rather just the risk of capital loss if the bonds are sold prior to maturity. Recent events in both Europe and the United States may have made the traditional assumption less plausible.

${ }^{13}$ Most of the asset prices that we consider relate to large and liquid markets, such as stock and bond futures or foreign exchange. But for the corporate bond indices, there is a potential concern that prices may be stale. We investigated estimating equation (1) with two-day changes in corporate bond yields on the left-hand-side (changes from the day before the announcement to the day after). Coefficient estimates were generally bigger than using one-day changes, but the results were not qualitatively different.
} 
policy surprise has a smaller but significant effect on US ten-year yields, and the euro and Japanese monetary policy surprises have no significant effect on US tenyear yields. This asymmetry has been found in sample periods covering conventional monetary policy by researchers including Ehrmann and Fratzscher (2005), though Gürkaynak and Wright (2011) found that some non-US conventional monetary policy announcements also affect the US yield curve. Fratzscher et al. (2013) provide a detailed study of the effects of US unconventional monetary policy announcements and actions on global asset prices and portfolio flows.

The effects of monetary policy shocks on exchange rates and foreign interest rates are very important, as they represent unintended policy spillovers. Monetary policy easing by the Fed has offsetting effects on the rest of the world; it causes other currencies to appreciate viz-a-viz the dollar, but at the same time it reduces longerterm interest rates in other countries. Conversely, monetary policy easing by non-US central banks causes the dollar to appreciate, and may cause longer-term US interest rates to fall, but we find this latter effect only for UK easings, and even in this case it is small.

Results are generally similar using the wide window (Table 7). However, there are some differences. The estimated effect of an expansionary UK monetary policy surprise on the exchange value of the pound is smaller in the wide window than in the narrow window. The effect of an expansionary Japanese monetary policy surprise on stock prices is significantly negative in the wide window. In this case, we suspect that moving to the wider window has contaminated the monetary policy surprise with other shocks, which is the downside of using a wider window. 


\subsection{Euro-area monetary policy shocks}

Our measurement of monetary policy shocks in the euro area is different from that

for the other central banks. It might seem more natural to measure euro-area monetary policy surprises from intraday changes in German bond yields, as this would be more directly parallel to the treatment of the US, UK and Japan. However, the actions of the ECB over this particular period, as discussed the previous in section, were clearly aimed at intra-euro area sovereign spreads, not at the level of German interest rates. ECB President Draghi has emphasized the special importance of intra-euro area spreads in the transmission mechanism of monetary policy, under the unusual circumstances of the last few years. Indeed, actions that succeded in lowering sovereign spreads tended to drive German yields up. Thus, measuring monetary policy from German yields alone would result in the perverse conclusion that these actions, such as the OMT announcement, represented an attempt by the ECB to tighten financial conditions. Intra-euro area sovereign spreads reflect default risk and default risk premia that are normally thought of as being separate from monetary policy. But the special circumstances of the euro area in the last few years - where monetary policy was aimed at reducing default risk and risk premia - mean that it is appropriate to measure monetary policy differently. Consequently it is not surprising that monetary policy had quite different effects in the euro area and elsewhere.

\subsection{Comparison with Conventional Monetary Policy}

Our analysis in this paper applies only to the period of unconventional monetary policy. In this subsection we compare our findings with those of other studies that apply to the earlier period of conventional monetary policy. On pre-ZLB US data, Gürkaynak et al. (2005b) estimated that a 25 basis point surprise reduction in the 
federal funds rate caused ten-year yields to fall by about 10 basis points and stock prices to rise by about 2 percentage points. In our sample we find that a 25 basis point surprise reduction in the ten-year yield (without any change in the federal funds rate) causes stock prices to rise by 0.7 percentage points. The pre-ZLB and ZLB eras are thus estimated to be quite different. Clearly, monetary policy is working at different points on the term structure: It has the largest effects on short-term interest rates in conventional monetary policy, but the largest effects on long-term interest rates in unconventional policy. But, in addition, a given decline in long-term interest rates caused by monetary policy had a much larger effect on stock prices in the conventional monetary policy period than it does with unconventional policy. According to the estimates of Gürkaynak et al. (2005b), in the pre-ZLB period, the federal funds rate would have to be cut by about 60 basis points to lower ten-year yields by 25 basis points, and this should in turn boost stock prices by about 5 percentage points. Our estimates over the ZLB period are much smaller.

For the UK, we find no statistically significant effect of unconventional-period monetary policy surprises on stock prices; earlier studies from the pre-ZLB period found that surprise Bank of England easings had a significant positive effect on stock prices, although the magnitude was smaller than pre-ZLB estimates for the US (see, e.g. Bredin et al. (2007)).

We estimate that unconventional monetary policy surprise easings cause corporate credit spreads to increase (corporate yields fall, but by less than their sovereign counterparts). With conventional monetary policy, the empirical evidence indicates that surprise reductions in short-term policy interest rates cause corporate credit spreads to fall (see, e.g. Cenesizoglu and Essid (2012)).

In relation to the stock market and corporate yields, we thus find some evidence that while unconventional monetary policy has effects on these other markets, the 
ZLB constraint makes it less powerful than conventional monetary policy. Kiley (2013a,b) also reached this conclusion. On the other hand, the estimated effect on the foreign exchange value of the dollar of a monetary policy surprise that lowers ten-year Treasury yields is roughly similar with conventional and unconventional monetary policy (Glick and Leduc, 2013).

\subsection{Econometric Comment}

The concerns with window size in estimating equation (1) have motivated some researchers, such as Kiley (2013b) and Gilchrist et al. (2013) to consider an instrumental variables (IV) strategy. This methodology involves estimating the regression using daily changes, but instrumenting the daily change in yields on the right-hand-side with an intraday change in yields around the monetary policy announcement. However, there is a strong presumption in finance that the serial correlation of yield changes in adjacent windows is small. ${ }^{14}$ Given this presumption, the population expectation of the daily yield change conditional on the intradaily yield change should be equal to the intraday yield change. Since an IV estimator can be interpreted as the OLS estimator, replacing the right-hand-side variable with its projection onto the instrument, this means that the IV estimator should be the same in large samples as just running an OLS regression with the intraday yield change on the right-hand-side. In small samples they will be different, but that is because there happens to be some serial correlation in yield changes in a particular sample. Since we think that any serial correlation in yield changes is best thought of as a "fluke", we prefer not to rely on it, and consequently just run the regression in equation (1) by OLS, with intradaily changes as the right-hand-side variable. If the intraday window includes

\footnotetext{
${ }^{14}$ If a yield change in one part of the day is serially correlated with a yield change in a later part of the day, then it implies a massive failure of efficient markets.
} 
shocks other than the monetary policy surprise, then this method will fail, but so will the IV strategy. If this is the concern, then identification through heteroskedasticity is the appropriate econometric technique, and we consider this in section 5 below.

\subsection{Effects of Different Types of Announcements}

Generally in this paper, we are examining the composite effects of unconventional monetary policy, without decomposing it into forward guidance, asset purchases, policies to relieve strains in particular markets and so on. But in this subsection we attempt to break out the effects of different types of announcements. We adopt two methods to do this.

\subsubsection{Judgmental Classification of Announcements}

The first method that we consider is to split monetary policy announcements into different types. For the Fed, we split announcements into those that we view as predominantly containing news about LSAPs and the other announcements, as marked in Table 1. There are of course many announcements that have elements of both, which is the limitation of this method, but we nevertheless attempt to put each announcement into one of these categories. ${ }^{15}$ Then we estimate equation (1) using the narrow window for LSAP and other announcement days separately. The results are reported in Table 8. The monetary policy shock has a larger effect on two-year yields on non-LSAP days than on LSAP days, which makes sense because forward rate guidance is the most important unconventional policy other than asset purchases, and its effects should be concentrated on the short end of the yield curve. LSAP announcements have significant effects on corporate bond yields and the stock market, whereas

\footnotetext{
${ }^{15}$ Our classification of FOMC announcements is similar to, but not the same as, that of Gilchrist et al. (2013).
} 
non-LSAP announcements do not.

The same approach applies to the other central banks. For the BOE and BOJ, we split announcements into those that were primarily concerned with the asset purchase programmes and other announcements, as marked in Tables 2 and 4. For the ECB, we split announcements into those based on bond purchases, those based on LTROs, and other announcements, as marked in Table 3.

Tables 9, 10 and 11 report the results from estimating equation (1) for these different announcement types for the BOE, ECB and BOJ, respectively.

For the BOE (Table 9), monetary policy shocks are estimated to a have significant effect on the exchange rate both on asset purchase and other announcements, but the magnitude of the response is larger on asset purchase days. Monetary policy shocks are estimated to have a significant effect on corporate bond yields on asset purchase days, but not on other days.

For the ECB (Table 10), bond purchase and LTRO announcements both reduce Italian and Spanish yields and boost stock prices, and all of these effects are statistically significant. Other announcements reduce Italian yields, raise German yields, and have a smaller but significant positive effect on stock prices.

For the BOJ (Table 11), the asset purchase announcements are estimated to have a larger effect on the dollar-yen exchange rate and on stock prices than other monetary policy announcements.

Broadly, our results in Tables 8-11 suggest that-to the extent that we can separate unconventional monetary policy announcements into those that concern asset purchases and those that do not - the pass-through from the former is generally larger. 


\subsubsection{Two dimensions of monetary policy measured from the yield curve}

The second method that we consider for examining the effects of different kinds of central bank announcements is applicable to the US alone, because this is the only country for which our intradaily data gives us yields at different maturities (Table 5). For the US, we measure a two-dimensional surprise on monetary policy announcement days: the first two principal components of the change in two-, five- and ten- and thirty-year Treasury futures yields. We then consider regressions of the form:

$$
\Delta y_{t}=\beta_{1} M P S_{1 t}+\beta_{2} M P S_{2 t}+\varepsilon_{t}
$$

where $M P S_{1 t}$ and $M P S_{2 t}$ denote the two kinds of monetary policy surprises. The results are reported in Table 12 (using the narrow window). The first monetary policy surprise raises all rates, but especially at the long end. We interpret this as an expansionary LSAP shock. The second monetary policy surprise rotates the yield curve, pushing short rates down and long rates up. We interpret this as forward guidance shock. The first monetary policy shock has large and significant effects; it drives all yields including corporate yields down, causes the dollar to depreciate, and stock prices to rise. The second monetary policy shock rotates the Treasury yield curve, but has no significant effect on stock prices, corporate bond yields or the foreign exchange value of the dollar.

However, an expansionary value of the second (non-LSAP) monetary policy shock on the MOVE index is significantly negative. As forward guidance is the most significant non-LSAP element to US monetary policy, this suggests an important mechanism through which forward guidance may be effective, that has received little emphasis in the literature. Forward guidance may not only lower the expected path of monetary policy, but it may also reduce uncertainty about future policy, and thereby lower term 
premia $^{16}$ (see Akkaya (2014) for further discussion of this possibility).

\subsection{Asymmetry}

It is possible that surprise tightenings and easings of monetary policy might have different effects on asset prices. The possibility has been investigated in the context of conventional monetary policy (e.g. Kuttner (2001)) and little evidence for asymmetry has been found. It is a bit difficult to investigate in the context of unconventional monetary policy because most (but not all) surprises have been easings.

Nonetheless, to attempt to investigate the possibility, we augmented equation (1) with an interaction with a sign dummy, considering the specification:

$$
\Delta y_{t}=\beta_{1} M P S_{t}+\beta_{2} M P S_{t} 1\left(M P S_{t}>0\right)+\varepsilon_{t}
$$

Our focus is on $\beta_{2}$. Estimates of the coefficients in equation (3) are reported for some asset prices in Table 13 (using the narrow window). In interpreting these results, recall that a positive value of $M P S_{t}$ refers to a surprise easing. In most cases $\beta_{2}$ is not statistically significant. But it is statistically significant for the effects of monetary policy surprises on stock returns in the US and the UK (at the 10 percent level in the latter case). The interpretation of the estimated coefficient is that the boost to stocks from an expansionary monetary policy shock is larger in magnitude than the negative impact on stocks of a surprise monetary policy tightening.

\footnotetext{
${ }^{16}$ Term premia are important (and time-varying) even for fairly short-term interest rates (Piazzesi and Swanson, 2008)
} 


\subsection{Crisis and non-crisis subsamples}

One might wonder if the effects of monetary policy shocks were different during the acute phase of the global financial crisis. Models of market segmentation suggest that asset purchases should be particularly effective in lowering the prices of the assets being purchased when arbitrage capital is scarce and markets are not functioning normally (Vayanos and Vila, 2009; Greenwood and Vayanos, forthcoming). Multiple equilibria stories are also more persuasive in times of crises. IMF (2013) suggest that asset purchases may be most effective at times of crises. However, this paper is mainly concerned with estimation of pass-through - given an $\mathrm{x}$ basis point drop in domestic government bond yields caused by unconventional monetary policy, we study the spillover effects on other asset prices. This kind of pass-through might be smallest when arbitrage capital is scarcest.

To investigate the question empirically, we estimated equation (1) using the narrow window for all four central banks, splitting the sample into subsamples for 2008 and 2009 and other years. We view these as crisis and non-crisis subsamples. Coefficient estimates are reported in Table 14. For the Fed and BOE, the main difference between the crisis and non-crisis subsamples is that the standard errors tend to be bigger in the latter, because all the big surprises happened in 2008 and 2009. There is no consistent pattern of pass-through being larger or smaller in the two subsamples. For the ECB, things are quite different. The standard errors are larger in the 2008/2009 subsample and pass-through into corporate yields, stock prices and the foreign exchange value of the euro is significant only in the other subsample. But this is not surprisingalthough 2008/2009 was the peak of the global financial crisis, the euro-specific crisis

came later. For the ECB, the largest monetary policy surprises were clearly in 2011 and 2012. For the BOJ, there were relatively large monetary policy surprises both 
during 2008/2009 and at other times (before and since). However, the significant effect of BOJ monetary policy surprises on the foreign exchange value of the yen was found only during the non-2008/2009 subsample.

\section{Persistence}

The method described in section 3 is intended to measure the immediate effect of monetary policy shocks on asset prices. It is obviously important to know how persistent these effects are. The normal presumption in the event study literature is that the effects are long-lasting (Fama et al., 1969). But there are several natural mechanisms that might cause the effects of unconventional monetary policy surprises to wear off over time including:

(1) Quantitative easing may make the economy recover faster than would otherwise have been the case, ultimately driving interest rates back up.

(2) Quantitative easing may induce more corporate issuance of long-term bonds (Stein, 2012), which would in turn also tend to push long-term rates higher.

(3) Frictions may make arbitrage capital slow-moving - and thus better able to offset the impact of preferred habitat investors in the long-run than in the short-run (Duffie, 2010; Mitchell et al., 2007).

(4) Many of the important unconventional monetary policy surprises took place at a time when financial markets were impaired, and so effects of asset purchases on bond yields may have been particularly large. As arbitrage capital returned to financial markets, the effects would have got smaller. 
(5) Some part of the effect of unconventional monetary policy surprises was to lower the near-term expected path of the federal funds rate. But, in the absence of any further news, the impact of this shift on the ten-year yield mechanically disappears with the passage of time.

Lou et al. (2013) document that the increase in Treasury supply associated with new auctions has an impact on bond prices, but that it wears off within days. Casual empiricism indicates that the effect of unconventional monetary policy announcements on asset prices does not wear off that fast. At same time, some tendency for the effects of policy shocks to weak off is arguably implicit in the results of existing studies, at least for the US. Gagnon et al. (2011) add up the announcement effects of LSAP announcements from November 2008 to November 2009 on ten-year yields, and find that it comes to 91 basis points. These announcements were essentially complete surprises, and so this is a natural way to assess their immediate impact. It is harder to measure the effects of FOMC actions since November 2009 on Treasury yields, because news about these did not come out in clear surprise announcements. But Li and Wei (2013) argue that as of 2012, all the LSAPs jointly had lowered ten-year Treasury yields by 100 basis points, and that seems a reasonable calibration. However, if these numbers are to be reconciled, then either the FOMC actions since November 2009 had minimal effects ${ }^{17}$, or else the 91 basis points of easing in 2008-2009 must have worn off, at least in part.

An approach for assessing persistence more formally is to use a VAR in daily asset price data. We briefly summarize the econometric method, discussed in more detail in Wright (2012). We assume that a $p x 1$ vector of yields, observed at the daily

\footnotetext{
${ }^{17}$ There is plenty of evidence against this; for example D'Amico et al. (2012) estimate that the second LSAP program lowered ten-year yields by 55 basis points.
} 
frequency, $Y_{t}$, has the reduced form VAR representation

$$
A(L) Y_{t}=\mu+\varepsilon_{t}
$$

where $\varepsilon_{t}$ denote the reduced form forecast errors. We further assume that these reduced form errors can be related to a set of underlying structural shocks

$$
\varepsilon_{t}=\sum_{i=1}^{p} R_{i} \eta_{i, t}
$$

where $\eta_{i, t}$ is the $i$ th structural shock, $R_{i}$ is a $p \times 1$ vector, and the structural shocks are independent of each other and over time. The monetary policy shock is ordered first, for notational convenience only.

We can then regress the reduced form errors onto the monetary policy shocks identified from intradaily data in section 3. This immediately gives us an estimate of $R_{1}$ and allows us to estimate the VAR. Inference can then done using the biasadjusted bootstrap of Kilian (1998).

We applied this method to data from the United States, United Kingdom, euro area, and Japan and fitted a VAR to daily data on two- and ten-year government bond yields and corporate yields as listed in Table 5. For the euro area, we fitted a VAR to daily data on ten-year Italian, Spanish and French spreads over their German counterparts, ten-year German bond yields, and corporate bond yields as listed in Table 5. In all cases the number of VAR lags was determined by the Bayes Information Criterion. The impulse responses function estimates and 90 percent bootstrap confidence intervals applying the method to the US, UK, euro area and Japan are reported in Figures 2-5, respectively. 
For the US, UK and Japan (Figures 2, 3 and 5), the effect of the monetary policy shock on ten-year government bond yields and on corporate bond yields is significant at short horizons. The persistence of the effects is not precisely estimated, but the point estimates indicate that the effects "wear off," but do so fairly slowly. For Japan, the effect on two-year yields is estimated to be very small, and not statistically significant, likely because two-year yields have been clearly constrained by the zero lower bound in Japan for the last few years.

For the euro area (Figure 4), the expansionary monetary policy shock lowers Italian, French and Spanish government bond spreads over their German counterparts, and the effect remains statistically significant for some time. The expansionary monetary policy shock is also estimated to raise German and corporate bond yields, but these impulse responses are only significant at the shortest horizons.

\section{Identification Through Heteroskedasticity}

The methodologies in the last two sections rely on the window being sufficiently small that the monetary policy announcement is the only shock within this window. This may be a reasonable approximation if the window is very short. But monetary policy announcements in the last few years have been complicated and may take time for markets to digest. ${ }^{18}$ And they are coupled with press conferences that come a bit later. That motivates a winder window, which in turn makes it likely that other shocks will come in that contaminate the monetary policy surprise.

An alternative approach is given by identification through heteroskedasticity. This does not require us to assume that monetary policy surprises are directly measurable.

\footnotetext{
${ }^{18}$ For example, the word count of FOMC statements has on average gone from around 200 in 2008 to over 600 in 2013 . The more recent statements have addressed the size and composition of LSAPs, calendar and forward guidance, exit principles, etc.
} 
Instead, it uses daily data and posits that in the structural VAR model given by equations (4) and (5), the structural monetary policy shock $\eta_{1, t}$ has mean zero and variance $\sigma_{1}^{2}$ on announcement days, and variance $\sigma_{0}^{2}$ on all other days, while all other structural shocks are identically distributed on all days. The identifying assumption is that $\sigma_{0}^{2} \neq \sigma_{1}^{2}$. We just need to know that there is something special about monetary policy days, not that we are actually able to measure the surprise. Suppose that there are $T_{0}$ non-announcement days and $T_{1}$ announcement days. Let $\Sigma_{0}$ and $\Sigma_{1}$ denote the variance-covariance matrices of reduced form errors $\varepsilon_{t}$ on non-announcement and announcement days, respectively. Clearly,

$$
\Sigma_{1}-\Sigma_{0}=R_{1} R_{1}^{\prime} \sigma_{1}^{2}-R_{1} R_{1}^{\prime} \sigma_{0}^{2}=R_{1} R_{1}^{\prime}\left(\sigma_{1}^{2}-\sigma_{0}^{2}\right)
$$

This allows $R_{1}$ to be identified. Without loss of generality, we adopt the normalization that $\sigma_{1}^{2}-\sigma_{0}^{2}=1$, as $R_{1} R_{1}^{\prime}$ and $\sigma_{1}^{2}-\sigma_{0}^{2}$ are not separately identified. The econometric strategy is to estimate the VAR and construct the sample variance-covariance matrices of residuals on non-announcement and announcement days, $\hat{\Sigma}_{0}$ and $\hat{\Sigma}_{1}$, respectively. Then the parameters in the vector $R_{1}$ can be estimated by solving the minimum distance problem:

$\hat{R}_{1}=\arg \min _{R_{1}}\left[\operatorname{vech}\left(\hat{\Sigma}_{1}-\hat{\Sigma}_{0}\right)-\operatorname{vech}\left(R_{1} R_{1}^{\prime}\right)\right]^{\prime}\left[\hat{V}_{0}+\hat{V}_{1}\right]^{-1}\left[\operatorname{vech}\left(\hat{\Sigma}_{1}-\hat{\Sigma}_{0}\right)-\operatorname{vech}\left(R_{1} R_{1}^{\prime}\right)\right]$

where $\hat{V}_{0}$ and $\hat{V}_{1}$ are estimates of the variance-covariance matrices of $\operatorname{vech}\left(\hat{\Sigma}_{0}\right)$ and $\operatorname{vech}\left(\hat{\Sigma}_{1}\right)$. Armed with $\hat{R}_{1}$, estimates of the impulse responses can then be traced out.

We fitted exactly the same VARs to daily data as in the previous section, with the lag length again determined by the Bayes Information Criterion. We then applied 
identification through heteroskedasticity to measure the dynamic effects of monetary policy shocks on other asset prices, taking the measure of monetary policy as being ten-year government bond yields in the US, UK and Japan, and the spread between Italian and German bond yields for in euro area. For the Fed, the BOE and BOJ, we normalize the monetary policy shock to lower ten-year government bond yields by 25 basis points; for the ECB, we normalize the monetary policy shock to lower Italian bond yields by 25 basis points.

Table 15 reports the results of tests of the hypothesis that $\Sigma_{0}=\Sigma_{1}$ (announcement and non-announcement days are identical) and of the hypothesis that the difference between the two variance-covariance matrices can be factored in the form $R_{1} R_{1}^{\prime}$ (the data can be well characterized by a single monetary policy shock) for all four currency areas. Bootstrap p-values are also included. Identification through heteroskedasticity requires the first hypothesis to be rejected and the second to be accepted.

For the US and euro area, the hypothesis that the announcement and nonannouncement days are identical is decisively rejected, which is of course essential to identification through heteroskedasticity. For the UK, the results of this test are borderline with a $p$-value of 5.2 percent. For Japan, the test fails to reject, meaning that the identification is weak. Arai (2013) gives a detailed application of the identification-through-heteroskedasticity method to Japan, addressing the issue of weak identification. He finds that identification is helped by considering a subset of especially important monetary policy announcements.

The hypothesis of a one-dimensional monetary policy shock is not rejected for any of the four currency areas.

For our set of announcement days, we can only be confident in identification through heteroskedasticity working well for the US and the euro area. We thus report impulse responses for the US and euro area alone. These are given in Figures 
6 and 7 , respectively.

The confidence intervals in Figures 6 and 7 are very wide. For the US (Figure 6), the effect on corporate bond yields is significant, but only for a short time. Likewise, for the euro area (Figure 7), the effect of the monetary policy on Italian-German and Spanish-German sovereign bond spreads is significant, but only at short horizons, while the shock has no significant effect on any other yields or spreads in the VAR, at any horizon.

\section{Discussion}

The evidence from the last three sections points to monetary policy shocks having substantial impacts on government bond yields which in turn pass through to other asset prices, although to varying extents.

From the view-point of conventional asset pricing theory, the effects of monetary policy shocks on government bond yields are surprising. Models with preferred habitat investors - such as Modigliani and Sutch $(1966,1967)$ and, more recently, Vayanos and Vila (2009) and Greenwood and Vayanos (forthcoming) - can go some way to explain why asset purchase announcements have very material effects of bond yields. But in these preferred habitat models, and also in the empirical work of Hamilton and $\mathrm{Wu}$ (2012), LSAPs are viewed as influencing yields by reducing the supply of government bonds in the market.

A potential issue with this explanation is that there are other factors that produce large shifts in the effective supply of government bonds, and in this story they should all have comparable effects on yields. One example is government bond issuance - the rising issuance of US Treasuries coupled with the deliberate policy of the Treasury to increase the maturity of outstanding debt has been a force of larger 
magnitude than the Fed's LSAPs and of opposite sign. If we think that LSAPs lowered ten-year Treasury yields by 100 basis points (Li and Wei, 2013), and we think of all shifts in effective government bond supply as equivalent, then Treasury issuance must have raised ten-year Treasury yields by at least 200 basis points. If so, then notwithstanding safe-haven flows into Treasuries, it may seem a bit surprising that Treasury yields have remained so low.

But it may be that central bank announcements about LSAPs have effects over and above the direct effects of reducing the supply of bonds in the market. Arguably, they are signaling that they will expand asset purchases and other programs as much as needed to drive term premia and risk premia down, and to restore financial stability. If so, the credible signal is perhaps itself enough to drive yields down. The case for this seems especially clear for Europe. One can argue that there are multiple equilibria, as in the model of Jeanne (2012). In one equilibrium, default is likely and sovereign bond risk premia are high, ensuring an elevated probability of default. In the other equilibrium, default is unlikely and the risk premia are low. Central bank purchases - or even just the credible threat of such purchases - may have been enough to switch the euro zone from the bad to the good equilibrium. Indeed, it is hard to find any other explanation for the calming of concerns about the viability of the single currency area around the time of the announcement of the OMT program in 2012. This is especially so because OMT has been enormously effective despite not involving any actual bond purchases (to date).

When a central banks buys long-term government bonds in a bid to boost demand, the pass-through of the resulting decline in government bond yields to other asset prices is of course essential to the policy accomplishing its goal. The Fed, BOE and BOJ did not undertake government bond purchases with the aim of lowering government bond yields per se. Krishnamurthy and Vissing-Jorgenson (2013) argue that 
Fed purchases of Treasury had small spillover effects on other asset prices. Our reading of the evidence as studied by us and other researchers is that there is considerable pass-through, and we think that Krishnamurthy and Vissing-Jorgenson substantially understate its magnitude. That said, it stands to reason that if a central bank wants to lower the interest rate on a particular security, the best way is to buy that particular security. For example, as noted by Krishnamurthy and Vissing-Jorgenson, if

the goal is to lower MBS rates, buying MBS will have a bigger impact than buying government bonds. However, there are operational and legal restrictions that limit the capacity of central banks to buy private sector assets. The Fed could not operationally have doubled the size of its "QE3" MBS purchase program, nor could it legally have bought stocks or corporate bonds, or issued its own mortgages. Unconventional monetary policy seems to be at least somewhat effective in easing financial conditions even at the zero lower bound, but the tools of unconventional policy are limited.

\subsection{Politics and unconventional monetary policy}

There are also political economy issues associated with unconventional monetary policy. Central banks can act quickly in a crisis, and can take the blame for politically unpopular decisions away from elected politicians, but monetary policy is not always the best way of accomplishing objectives, and in any case this strategy imperils the independence of central banks in the long run. There are elements of this dilemma everywhere, but especially in Europe. The ECB always had the means to quell the euro-zone crisis by expressing willingness to buy sovereign bonds in unlimited quantities. Despite some protestations to the contrary, it cannot have been impossible, or illegal, because they ultimately did it. Front-loading this and the other actions 
that the ECB ultimately took would have spared Europe the worst of the economic downturn. But it would also have taken the pressure off politicians for reforms that were needed, or perceived to be needed. Also, it is easier for central banks to justify unusual measures to politicians and the public once a crisis is clearly underway than to do so pre-emptively. Considerations of this sort surely slowed the willingness of the ECB to implement unconventional monetary policy.

\subsection{Effects of Reversing Unconventional Policy}

An important question going forward is the asset market effects of tapering and eventually unwinding asset purchases and other aspects of unconventional monetary policy. Our sample involves mostly surprise easings of policy, but at some point in the future, there will be surprise policy tightenings. The natural presumption would be that monetary policy tightening shocks will have similar effects, but of opposite sign. The response of the markets to Chairman Bernanke's testimony on May 22, 2013, and to the FOMC meeting on June 19, 2013, as discussed earlier, appears broadly consistent with this presumption. But in subsection 3.6, we did find some hint of an asymmetry whereby the stock market reaction to a surprise monetary policy tightening is smaller than the reaction to a surprise monetary policy easing. One can imagine reasons why some financial markets might potentially be more sensitive to asset purchases than to their subsequent unwinding. Unconventional monetary policy announcements can be interpreted as the central bank signaling that it will do whatever it takes to ease financial conditions. But shrinking the balance sheet in the future is unlikely to be part of a correspondingly deliberate and open-ended attempt to tighten financial conditions. Still, the jury is still out on how tapering and the eventual unwinding of unconventional monetary policy will impact financial markets. 
The four central banks are likely to unwind unconventional policy at rather different times, which makes the cross-country spillover effects that we have estimated especially important. For example, at the time of writing, it seems that the Federal Reserve will seek to withdraw policy accommodation sooner than the ECB. We estimate that a policy action that raises ten-year US yields by 50 basis points of raising German ten-year yield by about 20 basis points, but also causes the euro to depreciate relative to the dollar by roughly 2 percent (based on the estimates in Tables 6 and 7). This would imply a depreciation of the trade-weighted effective value of the euro of about 0.4 percent. The interest rate and exchange rate spillovers work in opposite directions, but on net this scenario would strike us as representing an effective tightening of euro area financial conditions. If the ECB wanted to offset this spillover, then their own monetary policy would have to become even more accommodative.

\section{Conclusions}

In the aftermath of the Great Recession, major central banks have driven short rates to what is effectively the zero lower bound. It is a difficult situation which leaves at least the potential for a vicious circle in which deflation with a zero nominal interest rate drives real rates up, further adding to deflationary pressure (Williams and Reifschneider, 2000). Moreover, nothing like this has happened on a global scale since the Great Depression.

Alas, political constraints limit the ability of fiscal policy to boost demand, and monetary policy is left as the only source of stimulus in the United States, the United Kingdom and the euro zone. It is not a happy circumstance for central banks, yet monetary policy is not impotent at the zero lower bound. In this paper, we have studied the effects of unconventional monetary policy on bond yields, stock prices 
and exchange rates for the Fed, BOE, ECB and BOJ, using common methodologies with daily and especially intradaily asset price data. We find that these policies are indeed effective in easing broad financial conditions - not just lowering government bond yields - when policy rates are stuck at the zero lower bound. This appears to work largely by reducing term premia, and indeed driving them negative. The flipside of this is that the recovery, when it happens, will involve a substantial increase in long-term yields, a foretaste of which was seen in the summer of 2013.

The pass-through from bond yields into other asset prices generally seems to be bigger for the US than for other countries. There are also important cross-country spillovers, but they are asymmetric - the effects of US monetary policy shocks on non-US yields are larger than the other way round.

We have provided some comparison between the efficacy of asset purchases and other unconventional monetary policies. We obtained no strong and consistent resultperhaps reflecting the great difficulty of disentangling these two. However, at least in the US, UK and Japan, the asset purchase announcements generally seem to have more pass-through into asset prices other than government bond yields.

We have also attempted to estimate the persistence of effects of monetary policy surprises. This is difficult to identify with much precision, but our point estimates indicate that the effects wear off, although slowly. That implies that is not just the stock of central bank purchases of securities that matters for financial conditions, but also the flow.

Our focus in this paper has been on the effects of unconventional monetary policy on asset prices. A separate but different research agenda is to measure the effects of unconventional monetary policy on macroeconomic outcomes (see, for example, Giannone et al. (2011) and Lenza et al. (2010)). This latter task is perhaps more important, but also quite hard. We directly observe asset prices at the daily and 
intradaily frequency, and so can measure the effects of news on these prices, as we have done in this paper. Applying these techniques to macroeconomic outcomes and expectations is more involved. However, the finding that the unconventional monetary policies of the four central banks have eased broad financial conditions means that they surely helped somewhat with respect to both reducing the output gap and preventing inflation from falling too far below target. 


\section{Table 1: Dates and Times of US Monetary Policy Announcements}

\begin{tabular}{|c|c|c|c|}
\hline Year & Day & $\begin{array}{c}\text { Time } \\
(\text { New York) }\end{array}$ & Description \\
\hline \multirow[t]{5}{*}{2008} & $10 / 8$ & $7: 00$ & FFTR decreased to $1.5 \%$ \\
\hline & $10 / 29$ & $14: 15$ & FFTR decreased to $1 \%$ \\
\hline & $11 / 25$ & $8: 15$ & $\begin{array}{l}\text { Fed Announces Purchases of MBS } \\
\text { and Agency Bonds }\end{array}$ \\
\hline & $12 / 1$ & $13: 45$ & Bernanke states Treasuries may be purchased \\
\hline & $12 / 16$ & $14: 15$ & FOMC Meeting: FFTR decreased to $0-0.25 \%$ \\
\hline \multirow[t]{5}{*}{2010} & $1 / 27-3 / 16-4 / 28-6 / 23-\mathbf{8} / \mathbf{1 0}$ & $14: 15$ & FOMC Meeting \\
\hline & $8 / 27$ & 10:00 & Bernanke Speech at Jackson Hole \\
\hline & $9 / 21$ & $14: 15$ & FOMC Meeting \\
\hline & $10 / 15$ & $8: 15$ & Bernanke Speech at Boston Fed \\
\hline & $\mathbf{1 1 / 3}-12 / 14$ & $14: 15$ & FOMC Meeting \\
\hline \multirow[t]{2}{*}{2011} & $1 / 26-3 / 15-4 / 27(12: 30)-6 / 22(12: 30)-8 / 9$ & $14: 15$ & FOMC Meeting \\
\hline & $8 / 26$ & 10:00 & Bernanke Speech at Jackson Hole \\
\hline \multirow{2}{*}{2012} & $8 / 31$ & 10:00 & Bernanke Speech at Jackson Hole \\
\hline & 9/13(12:30) - 10/24 - 12/12(12:30) & $14: 15$ & FOMC Meeting \\
\hline \multirow[t]{3}{*}{2013} & $1 / 30-3 / 20(14: 00)-5 / 1(14: 00)$ & $14: 15$ & FOMC Meeting \\
\hline & $5 / 22$ & 10:00 & Bernanke Testimony \\
\hline & $6 / 19$ & $14: 00$ & FOMC Meeting \\
\hline
\end{tabular}

Notes: Date only is an FOMC meeting, time is 14:15 unless otherwise indicated. Entries in bold denote the announcements that we treat as LSAP announcements; all other announcements are treated as non-LSAP. 


\section{Table 2: Dates and Times of UK Monetary Policy Announcements}

\begin{tabular}{|c|c|c|c|}
\hline$\overline{\text { Year }}$ & Day & $\begin{array}{c}\text { Time } \\
\text { (London) }\end{array}$ & Description \\
\hline \multirow[t]{3}{*}{2008} & $10 / 8$ & $12: 00$ & MPC meeting, bank rate decreased to $4.5 \%$ \\
\hline & $11 / 6$ & $12: 00$ & MPC meeting, bank rate decreased to $3 \%$ \\
\hline & $12 / 4$ & $12: 00$ & MPC meeting, bank rate decreased to $2 \%$ \\
\hline \multirow[t]{13}{*}{2009} & $1 / 8$ & $12: 00$ & MPC meeting, bank rate decreased to $1.5 \%$ \\
\hline & $1 / 19$ & $12: 00$ & $\begin{array}{l}\text { The chancellor of the Exchequer } \\
\text { announces the BOE will set up an APF }\end{array}$ \\
\hline & $1 / 29$ & $12: 00$ & Asset Purchase Facility announcement \\
\hline & $2 / 5$ & $12: 00$ & MPC meeting, rate decreased to $1 \%$ \\
\hline & $2 / 11$ & $12: 00$ & $\begin{array}{l}\text { Inflation report and press conference } \\
\text { give strong indication that QE is likely }\end{array}$ \\
\hline & $3 / 5$ & $12: 00$ & $\begin{array}{l}\text { APF announcement: } £ 75 \text { billion of Gilts, } 5 \text { - } 25 \text { years; } \\
\text { bank rate decreased to } 0.5 \%\end{array}$ \\
\hline & $4 / 9$ & $12: 00$ & MPC meeting \\
\hline & $5 / 7$ & $12: 00$ & APF extended to $£ 125$ billion \\
\hline & $6 / 4-7 / 9$ & $12: 00$ & MPC meeting \\
\hline & $8 / 6$ & $12: 00$ & APF extended to $£ 175$ billion, $3+$ yrs maturity \\
\hline & $9 / 10-10 / 8$ & $12: 00$ & MPC meeting \\
\hline & $11 / 5$ & $12: 00$ & APF extended to $£ 200$ billion \\
\hline & $12 / 10$ & $12: 00$ & MPC meeting \\
\hline \multirow[t]{3}{*}{2010} & $1 / 7$ & 12:00 & MPC meeting \\
\hline & $2 / 4$ & $12: 00$ & APF will be maintained at $£ 200$ billion \\
\hline & $3 / 44 / 8$ 5/6 $6 / 107 / 8$ 8/5 $9 / 9$ 10/7 $11 / 4$ 12/9 & $12: 00$ & MPC meeting \\
\hline \multirow[t]{3}{*}{2011} & $1 / 132 / 103 / 104 / 75 / 56 / 97 / 7$ 8/4 9/8 & $12: 00$ & MPC meeting \\
\hline & $10 / 6$ & $12: 00$ & APF extended to $£ 275$ billion \\
\hline & $11 / 1012 / 8$ & $12: 00$ & MPC meeting \\
\hline \multirow[t]{5}{*}{2012} & $1 / 12$ & $12: 00$ & MPC meeting \\
\hline & $2 / 9$ & $12: 00$ & APF extended to $£ 325$ billion, \\
\hline & $3 / 84 / 55 / 106 / 7$ & $12: 00$ & MPC meeting \\
\hline & $7 / 5$ & $12: 00$ & APF extended to $£ 375$ billion \\
\hline & $\begin{array}{llllll}8 / 2 & 9 / 6 & 10 / 4 & 11 / 8 & 12 / 6\end{array}$ & $12: 00$ & MPC meeting \\
\hline \multirow[t]{2}{*}{2013} & $1 / 102 / 73 / 74 / 4$ & $12: 00$ & MPC meeting \\
\hline & $5 / 9$ & $12: 00$ & MPC meeting \\
\hline
\end{tabular}

Notes: Entries in bold denote the announcements that we treat as APF announcements; all other announcements are treated as non-APF. 
Table 3: Dates and Times of ECB Monetary Policy Announcements

\begin{tabular}{|c|c|c|c|}
\hline Year & Day & $\begin{array}{l}\text { Time } \\
\text { (Frankfurt) }\end{array}$ & Description \\
\hline \multirow{5}{*}{2007} & $8 / 2$ & $13: 45$ & GC meeting \\
\hline & $8 / 9$ & $12: 32$ & Special fine-tuning operations \\
\hline & $8 / 22$ & $15: 33$ & Supplementary LTRO (announcement) \\
\hline & $8 / 23$ & $11: 18$ & Supplementary LTRO (allotment) \\
\hline & $9 / 6 \quad 10 / 4 \quad 11 / 8 \quad 12 / 6$ & $13: 45$ & GC meeting \\
\hline \multirow[t]{9}{*}{2008} & $1 / 102 / 73 / 6$ & $13: 45$ & GC meeting \\
\hline & $3 / 28$ & $15: 00$ & ECB introduces 6-m LTROs \\
\hline & $4 / 105 / 86 / 5$ & $13: 45$ & GC meeting \\
\hline & $7 / 3$ & $13: 45$ & GC meeting, MRO rate increased to $4.25 \%$ \\
\hline & $8 / 79 / 4$ & $13: 45$ & GC meeting \\
\hline & $10 / 8$ & $13: 00$ & GC meeting, MRO rate decreased to $3.75 \%$ \\
\hline & $10 / 8$ & & Fixed-rate full allotment (FRFA) on MROs \\
\hline & $11 / 6$ & $13: 45$ & GC meeting, MRO rate decreased to $3.25 \%$ \\
\hline & $12 / 4$ & $13: 45$ & GC meeting, MRO rate decreased to $2.50 \%$ \\
\hline \multirow[t]{8}{*}{2009} & $1 / 15$ & $13: 45$ & GC meeting, MRO rate decreased to $2.00 \%$ \\
\hline & $2 / 5$ & $13: 45$ & GC meeting \\
\hline & $3 / 5$ & $13: 45$ & GC meeting, MRO rate decreased to $1.50 \%$ \\
\hline & $4 / 2$ & $13: 45$ & GC meeting, MRO rate decreased to $1.25 \%$ \\
\hline & $5 / 7$ & $13: 45-14: 30$ & GC meeting, three 1yr LTROs, CBPP \\
\hline & $6 / 4^{*}$ & $13: 45-14: 30$ & GC meeting, CBPP details announced \\
\hline & $7 / 28 / 6 \quad 9 / 3 \quad 10 / 8 \quad 11 / 5$ & $13: 45$ & GC meeting \\
\hline & $12 / 3$ & $13: 45-14: 30$ & GC meeting, Phasing out of $6 \mathrm{~m}$ LTROs, indexation of $1 \mathrm{y}$ LTROs \\
\hline \multirow[t]{8}{*}{2010} & $1 / 14$ & $13: 45$ & GC meeting \\
\hline & $2 / 4$ & $13: 45$ & GC meeting \\
\hline & $3 / 4$ & $13: 45-14: 30$ & GC meeting, Phasing out of $3 \mathrm{~m}$ LTROs, indexation of $6 \mathrm{~m}$ LTROs \\
\hline & $4 / 85 / 6$ & $13: 45$ & GC meeting \\
\hline & $5 / 9 *$ & - & Securities Market Programme (SMP) \\
\hline & $6 / 107 / 8$ & $13: 45$ & GC meeting \\
\hline & $7 / 28$ & $13: 45$ & Collateral rules tightened, revised haircuts \\
\hline & $\begin{array}{llllll}8 / 5 & 9 / 2 & 10 / 7 & 11 / 4 & 12 / 2\end{array}$ & $13: 45$ & GC meeting \\
\hline \multirow[t]{12}{*}{2011} & $1 / 132 / 3$ & $13: 45$ & GC meeting \\
\hline & $\mathbf{3} / \mathbf{3}$ & $13: 45-14: 30$ & GC meeting, FRFA extended to July 2011 \\
\hline & $4 / 7$ & $13: 45$ & GC meeting, MRO rate increased to $1.25 \%$ \\
\hline & $5 / 56 / 9$ & $13: 45$ & GC meeting \\
\hline & $7 / 7$ & $13: 45$ & GC meeting, MRO rate increased to $1.50 \%$ \\
\hline & $8 / 4^{*}$ & $13: 45-14: 30$ & GC meeting, SMP covers Spain and Italy \\
\hline & $8 / 7^{*}$ & - & SMP on Italy and Spain acknowledged by ECB \\
\hline & $9 / 8$ & $13: 45$ & GC meeting \\
\hline & $10 / 6^{*}$ & 13:45-14:30 & GC meeting, CBPP2 launched \\
\hline & $11 / 3$ & $13: 45$ & GC meeting, MRO rate decreased $1.25 \%$ \\
\hline & $12 / 8$ & 13:45-14:30 & GC meeting: Two 3-year LTROs, reserve ratio to $1 \%$, MRO rate to $1 \%$ \\
\hline & $12 / 21$ & $11: 15$ & Results of first 3-year LTRO \\
\hline \multirow[t]{9}{*}{2012} & $1 / 12$ & $13: 45$ & GC meeting \\
\hline & $2 / 9$ & $13: 45$ & GC meeting, ECB approved criteria for credit claims for $7 \mathrm{NCBs}$ \\
\hline & $2 / 28$ & $11: 16$ & Results of second 3-year LTRO \\
\hline & $3 / 84 / 45 / 36 / 6$ & $13: 45$ & GC meeting \\
\hline & $7 / 5$ & $13: 45$ & GC meeting, MRO rate decreased to $0.75 \%$, deposit facility rate to 0 \\
\hline & $7 / 26^{*}$ & $11: 30-12: 15$ & "Whatever it takes" London speech \\
\hline & $8 / 2^{*}$ & $13: 45-14: 30$ & GC meeting, Outright Monetary Transactions (OMT) program \\
\hline & $9 / 6^{*}$ & $13: 45-14: 30$ & $\begin{array}{l}\text { GC meeting, OMT details released, no ex-ante size limit } \\
\text { Collateral rules eased }\end{array}$ \\
\hline & $10 / 411 / 812 / 6$ & $13: 45$ & GC meeting \\
\hline \multirow[t]{5}{*}{2013} & $1 / 102 / 73 / 7$ & $13: 45$ & GC meeting \\
\hline & $3 / 22$ & $15: 00$ & Collateral rule changes for some uncovered gov-guaranteed bank bonds \\
\hline & $4 / 4$ & $13: 45$ & GC meeting \\
\hline & $5 / 2$ & $13: 45$ & GC meeting: MRO rate to $0.5 \%$, FRFA extended to July 2014 \\
\hline & $6 / 6$ & $13: 45$ & GC Meeting \\
\hline
\end{tabular}

Notes: Entries in bold and bold with ${ }^{*}$ denote announcements that we treat as LTRO-type and bond purchases announcements, respectively. 14:30 is the start of the ECB press conference. The announcements on 5/9/2010 and 8/7/2011 are both on Sundays, when financial markets were closed. We take changes from market close to market open before/after the weekend for these dates. 


\section{Table 4: Dates and Times of Japanese Monetary Policy Announcements}

\begin{tabular}{|c|c|c|c|}
\hline Year & Day & $\begin{array}{l}\text { Time } \\
\text { (Tokyo) }\end{array}$ & Description \\
\hline \multirow[t]{4}{*}{2000} & $1 / 17(15: 50) 2 / 10(16: 15) 2 / 24(13: 20) 3 / 8(15: 50)$ & & Monetary policy meeting \\
\hline & $3 / 24(13: 25) 4 / 10(15: 45) 4 / 27(13: 35) 5 / 17(15: 40)$ & & Monetary policy meeting \\
\hline & $6 / 12(16: 00) 6 / 28(13: 10) 7 / 17(16: 15) 8 / 11(17: 30) 9 / 14(14: 50)$ & & Monetary policy meeting \\
\hline & $10 / 13(15: 45) 10 / 30(14: 40) 11 / 17(14: 55) 11 / 30(12: 40) 12 / 15(14: 45)$ & & Monetary policy meeting \\
\hline \multirow[t]{9}{*}{2001} & $1 / 19(16: 20) 2 / 9(17: 25)$ & & Monetary policy meeting \\
\hline & $2 / 28(16: 00)$ & & Call rate lowered to $0.15 \%$ \\
\hline & $3 / 19(17: 40)$ & & CAB increased to $¥ 5$ tr \\
\hline & $4 / 13(12: 30) 4 / 25(13: 00) 5 / 18(12: 30) 6 / 15(12: 25)$ & & Monetary policy meeting \\
\hline & $6 / 28(12: 55) 7 / 13(13: 10)$ & & Monetary policy meeting \\
\hline & $8 / 14(13: 15)$ & & CAB increased to $¥ 6$ tr \\
\hline & 9/18(19:00) & & Call rate lowered to $0.1 \%$ \\
\hline & $10 / 12(13: 15) 10 / 29(14: 10) 11 / 16(12: 45) 11 / 29(12: 35)$ & & Monetary policy meeting \\
\hline & $12 / 19(15: 05)$ & & CAB increased to $¥ 10-15$ tr \\
\hline \multirow[t]{6}{*}{2002} & $1 / 16(12: 50) 2 / 8(12: 30)$ & & Monetary policy meeting \\
\hline & $2 / 28(14: 05)$ & & increase LT bond purchases \\
\hline & $3 / 20(13: 35) 4 / 11(12: 25) 4 / 30(13: 10) 5 / 21(13: 10) 6 / 12(12: 25)$ & & Monetary policy meeting \\
\hline & $6 / 26(12: 55) 7 / 16(12: 30) 8 / 9(12: 50) 9 / 18(13: 20) 10 / 11(13: 00)$ & & Monetary policy meeting \\
\hline & $10 / 30(14: 45)$ & & CAB increased to $¥ 15-20$ tr \\
\hline & $11 / 19(13: 05) 12 / 17(13: 25)$ & & Monetary policy meeting \\
\hline \multirow[t]{8}{*}{2003} & $1 / 22(12: 35) 2 / 14(13: 25) 3 / 5(12: 45)$ & & Monetary policy meeting \\
\hline & $3 / 25(11: 55)$ & & CAB increased to $¥ 17-22$ tr \\
\hline & $4 / 8(13: 30)$ & & Monetary policy meeting \\
\hline & $4 / 30(13: 40) 5 / 20(13: 10)$ & & CAB increased to $¥ 22-27$ and $27-30$ tr \\
\hline & $6 / 11(13: 20)$ & & Monetary policy meeting \\
\hline & $6 / 25(12: 05)$ & & BoJ starts buying ABS \\
\hline & $7 / 15(11: 30) 8 / 8(11: 50) 9 / 12(13: 35) 10 / 10(14: 05)$ & & Monetary policy meeting \\
\hline & $10 / 31(12: 25) 11 / 21(12: 20) 12 / 16(11: 30)$ & & Monetary policy meeting \\
\hline \multirow[t]{5}{*}{2004} & $1 / 20(12: 50)$ & & CAB increased to $¥ 30-35$ tr \\
\hline & $2 / 5(12: 05) 2 / 26(12: 10) 3 / 16(12: 00) 4 / 9(12: 45)$ & & Monetary policy meeting \\
\hline & $4 / 28(13: 05) 5 / 20(12: 10) 6 / 15(11: 40) 6 / 25(11: 30)$ & & Monetary policy meeting \\
\hline & $7 / 13(12: 30) 8 / 10(11: 50) 9 / 9(11: 40) 10 / 13(12: 10)$ & & Monetary policy meeting \\
\hline & $10 / 29(13: 15) 11 / 18(12: 10) 12 / 17(12: 45)$ & & Monetary policy meeting \\
\hline \multirow[t]{4}{*}{2005} & $1 / 19(12: 40) 2 / 17(12: 10) 3 / 16(12: 50) 4 / 6(13: 15)$ & & Monetary policy meeting \\
\hline & $4 / 28(13: 15) 5 / 20(12: 55) 6 / 15(13: 10) 7 / 13(13: 00)$ & & Monetary policy meeting \\
\hline & $7 / 27(11: 45) 8 / 9(11: 55) 9 / 8(12: 40) 10 / 12(12: 30)$ & & Monetary policy meeting \\
\hline & $10 / 31(13: 00) 11 / 18(12: 55) 12 / 16(12: 40) 12 / 27(10: 00)$ & & Monetary policy meeting \\
\hline \multirow[t]{6}{*}{2006} & $1 / 20(13: 00) 2 / 9(12: 25) 3 / 3(6: 20)$ & & Monetary policy meeting \\
\hline & $3 / 9(14: 20)$ & & QEP ended \\
\hline & $4 / 11(12: 55) 4 / 28(12: 50) 5 / 19(12: 15) 6 / 15(12: 20)$ & & Monetary policy meeting \\
\hline & $7 / 14(13: 40)$ & & Call rate increased to $0.25 \%$ \\
\hline & $8 / 11(12: 20) 9 / 8(12: 40) 10 / 13(12: 50)$ & & Monetary policy meeting \\
\hline & $10 / 31(12: 50) 11 / 16(12: 25) 12 / 19(12: 30)$ & & Monetary policy meeting \\
\hline \multirow[t]{5}{*}{2007} & $1 / 18$ & 13:05 & Monetary policy meeting \\
\hline & $2 / 21$ & $14: 19$ & Call rate increased to $0.5 \%$ \\
\hline & $3 / 20(12: 40) 4 / 10(12: 48) 4 / 27(14: 07) 5 / 17(12: 41)$ & & Monetary policy meeting \\
\hline & $6 / 15(12: 18) 7 / 12(12: 55) 8 / 23(12: 35) 9 / 19(13: 21)$ & & Monetary policy meeting \\
\hline & $10 / 11(13: 32) 10 / 31(12: 42) 11 / 13(12: 29) 12 / 20(12: 51)$ & & Monetary policy meeting \\
\hline
\end{tabular}

Table continued on next page. 


\section{Table 4 (continued)}

\begin{tabular}{|c|c|c|c|}
\hline Year & Day & $\begin{array}{l}\text { Time } \\
\text { (Tokyo) }\end{array}$ & Description \\
\hline \multirow{4}{*}{2008} & $5 / 20(12: 04) 6 / 13(12: 23) 7 / 15(13: 34) 8 / 19(12: 30)$ & & Monetary policy meeting \\
\hline & $10 / 31$ & $13: 58$ & Call rate lowered to $0.3 \%$ \\
\hline & $11 / 21(12: 34) 12 / 2(14: 34)$ & & Monetary policy meeting \\
\hline & $12 / 19$ & 14:05 & Call rate lowered to $0.1 \%$ \\
\hline \multirow[t]{3}{*}{2009} & $1 / 22$ & $13: 43$ & Outright purchases (CPs, corp bonds) \\
\hline & $6 / 16(12: 347 / 15(13: 35) 8 / 11(11: 51) 9 / 17(12: 39)$ & & Monetary policy meeting \\
\hline & $10 / 14(13: 14) 10 / 30(13: 05) 11 / 20(12: 35)$ 12/1(15:38) 12/18(12:13) & & Monetary policy meeting \\
\hline \multirow[t]{4}{*}{2010} & $1 / 26(12: 26) 2 / 18(11: 45) 3 / 17(12: 49) 4 / 7(12: 03)$ & & Monetary policy meeting \\
\hline & $4 / 30(13: 18) 5 / 10(12: 11)$ & & Monetary policy meeting \\
\hline & $5 / 21(12: 42) 6 / 15(12: 56)$ & & Call rate unchanged, Fund-Provisioning \\
\hline & $7 / 15(12: 45) 8 / 10(12: 28)$ & & Monetary policy meeting \\
\hline \multirow[t]{8}{*}{2011} & $1 / 25(12: 29) 2 / 15(12: 37)$ & $12: 29$ & Monetary Policy meeting \\
\hline & $3 / 14$ & $14: 48$ & APP extended to $¥ 40$ tr \\
\hline & $4 / 7(13: 10) 4 / 28(13: 31)$ & & \\
\hline & $5 / 20(12: 14) 6 / 14(12: 42) 7 / 12(13: 20)$ & & Monetary Policy meeting \\
\hline & $8 / 4$ & 14:00 & APP extended to $¥ 50$ tr \\
\hline & $9 / 7(12: 21) 10 / 7(12: 37)$ & $12: 21$ & Monetary Policy meeting \\
\hline & $10 / 27$ & $13: 31$ & APP extended to $¥ 55 \mathrm{tr}$ \\
\hline & $11 / 16(12: 49) 11 / 30(22: 00) 12 / 21(12: 16)$ & $12: 49$ & Monetary Policy meeting \\
\hline \multirow[t]{5}{*}{2012} & $1 / 24$ & $12: 31$ & Monetary Policy meeting \\
\hline & $2 / 14$ & $12: 43$ & APP extended to $¥ 65 \mathrm{tr}$ \\
\hline & 3/13(14:07) 4/10(12:09) & & Monetary Policy meeting \\
\hline & $4 / 27$ & $12: 46$ & APP extended to $¥ 70$ tr \\
\hline & $5 / 23(11: 37) 6 / 15(11: 52)$ & & Monetary Policy meeting \\
\hline \multirow{3}{*}{2013} & $2 / 14(12: 39) 3 / 7(12: 24)$ & & Monetary Policy meeting \\
\hline & $4 / 4$ & $13: 40$ & Quantitative and Qualitative Monetary Easing \\
\hline & $4 / 26(13: 35) 5 / 22(12: 07) 6 / 11(11: 48)$ & & Monetary Policy meeting \\
\hline
\end{tabular}

Notes: Entries in bold denote the announcements that we treat as APP announcements; all other announcements are treated as non-APP. 


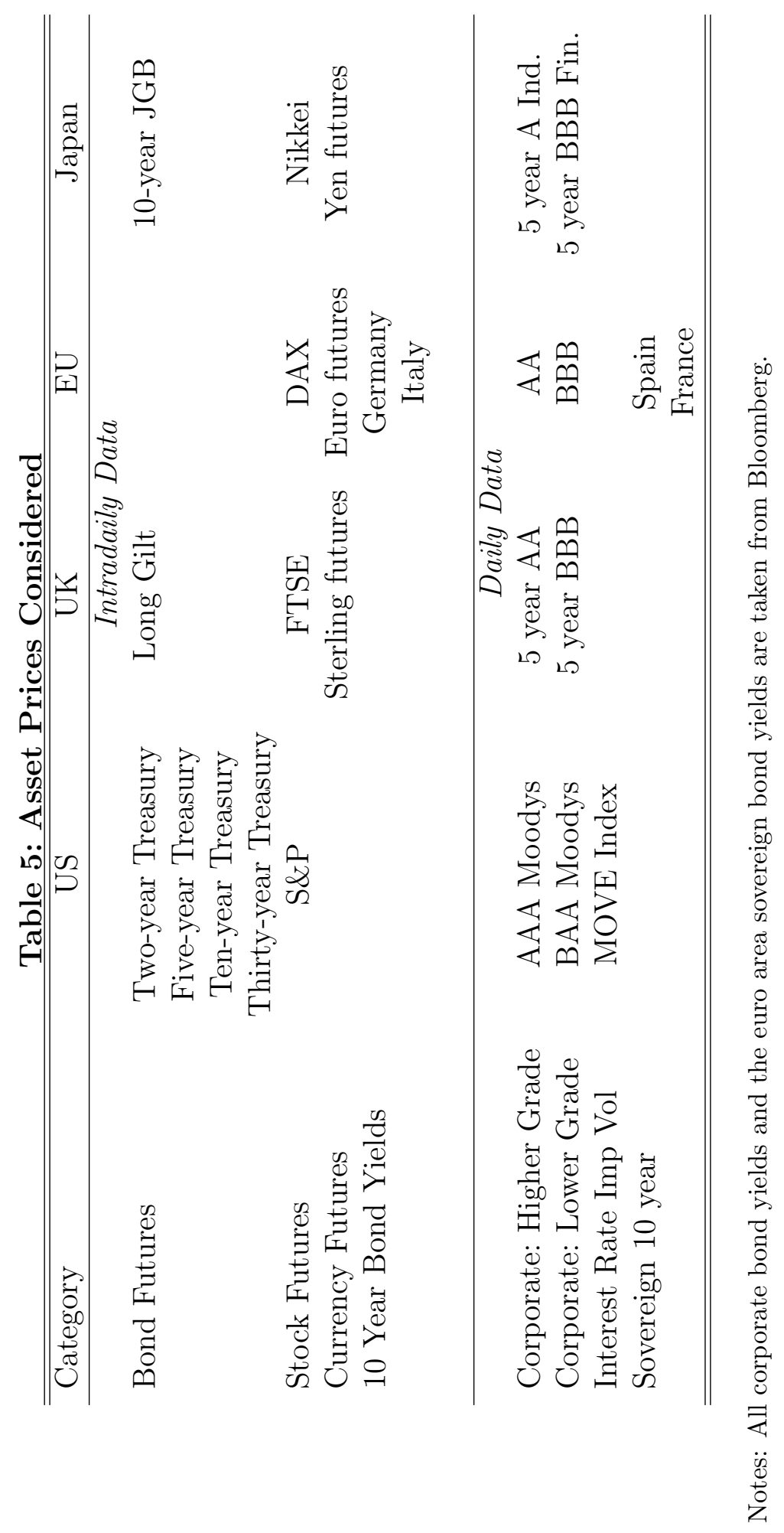




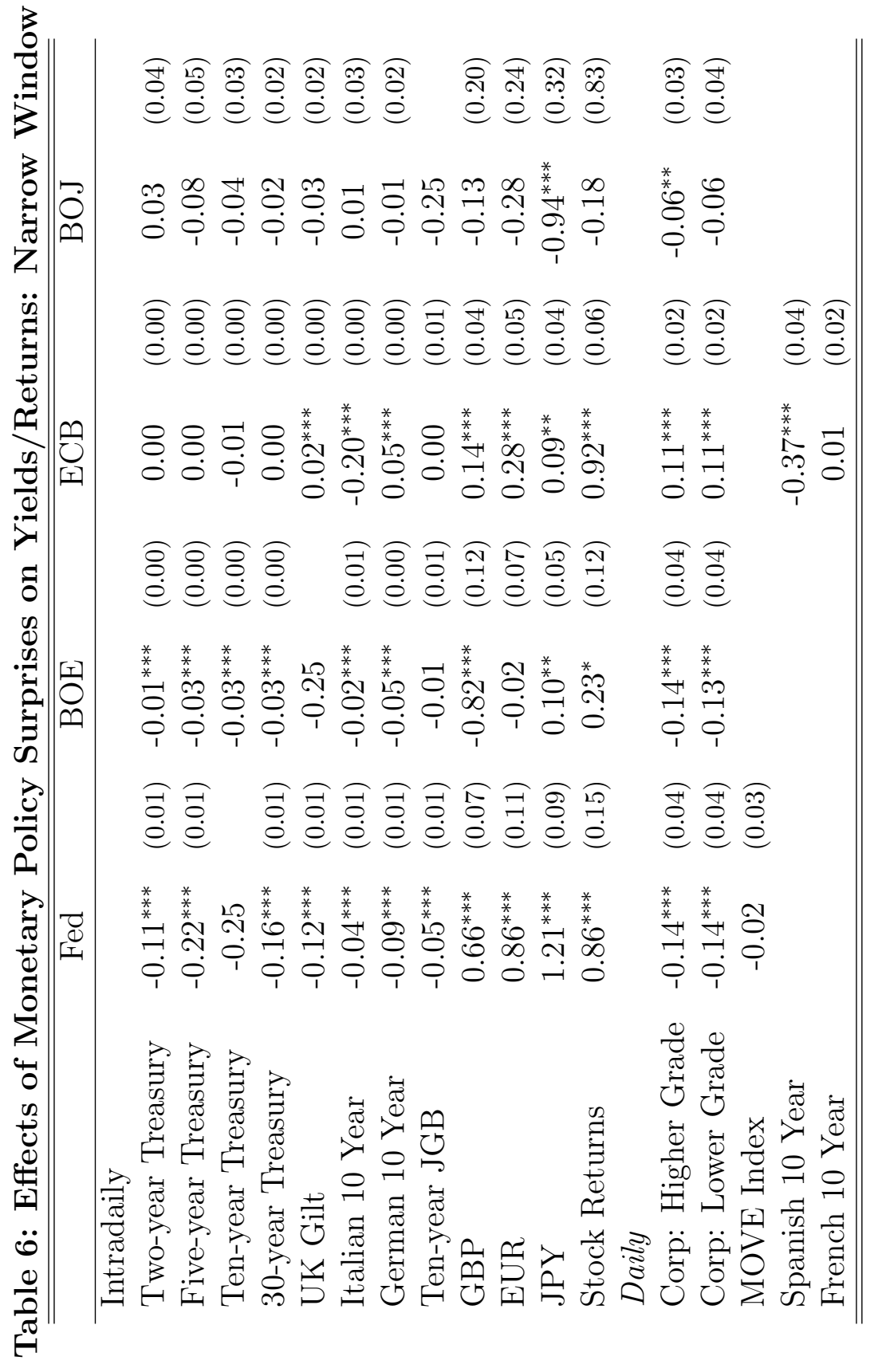

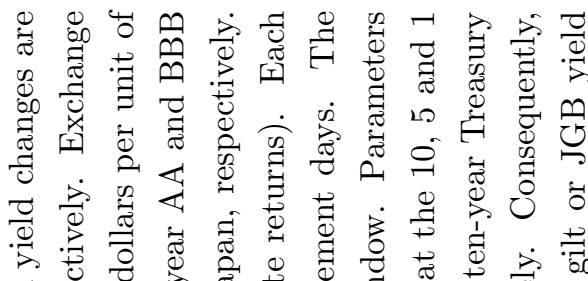

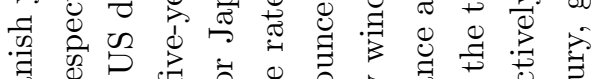

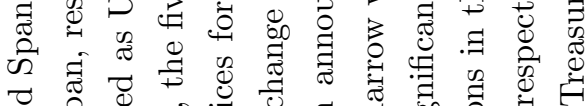

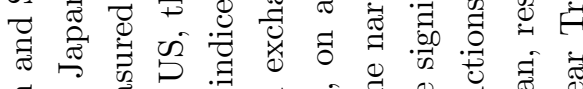

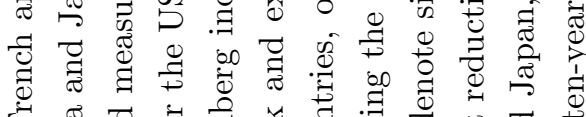

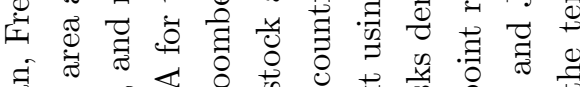

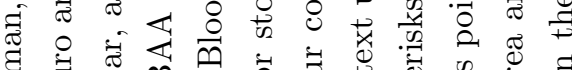
वृ ए सं च चै

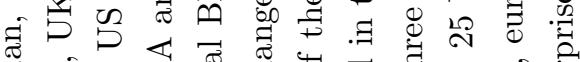
丞

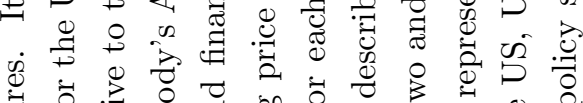

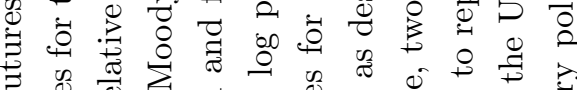
च घี

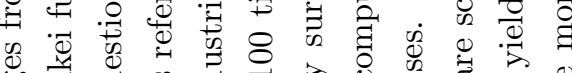
娄 శ్ च चี メ

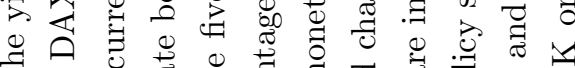

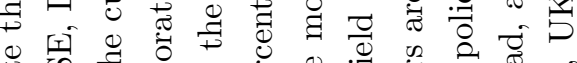
总 की

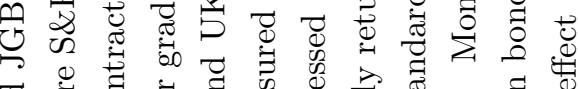

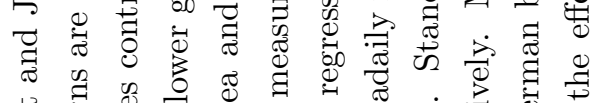

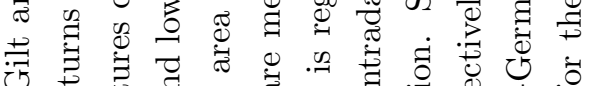

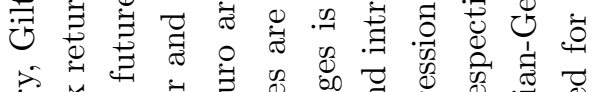

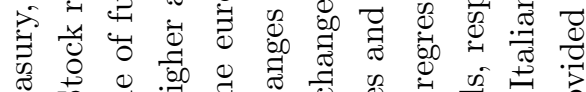
品

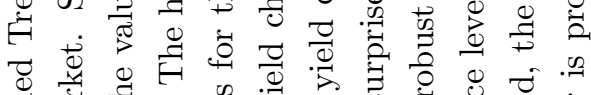

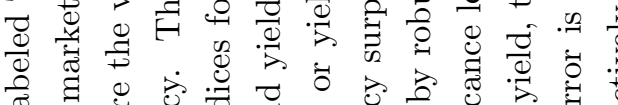
元 घ

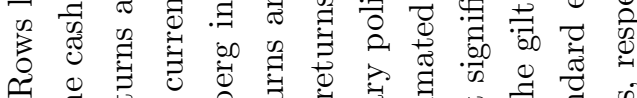
ح

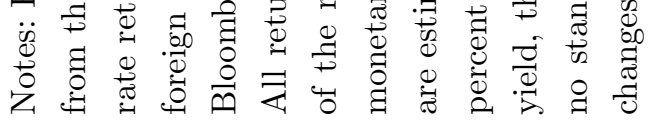




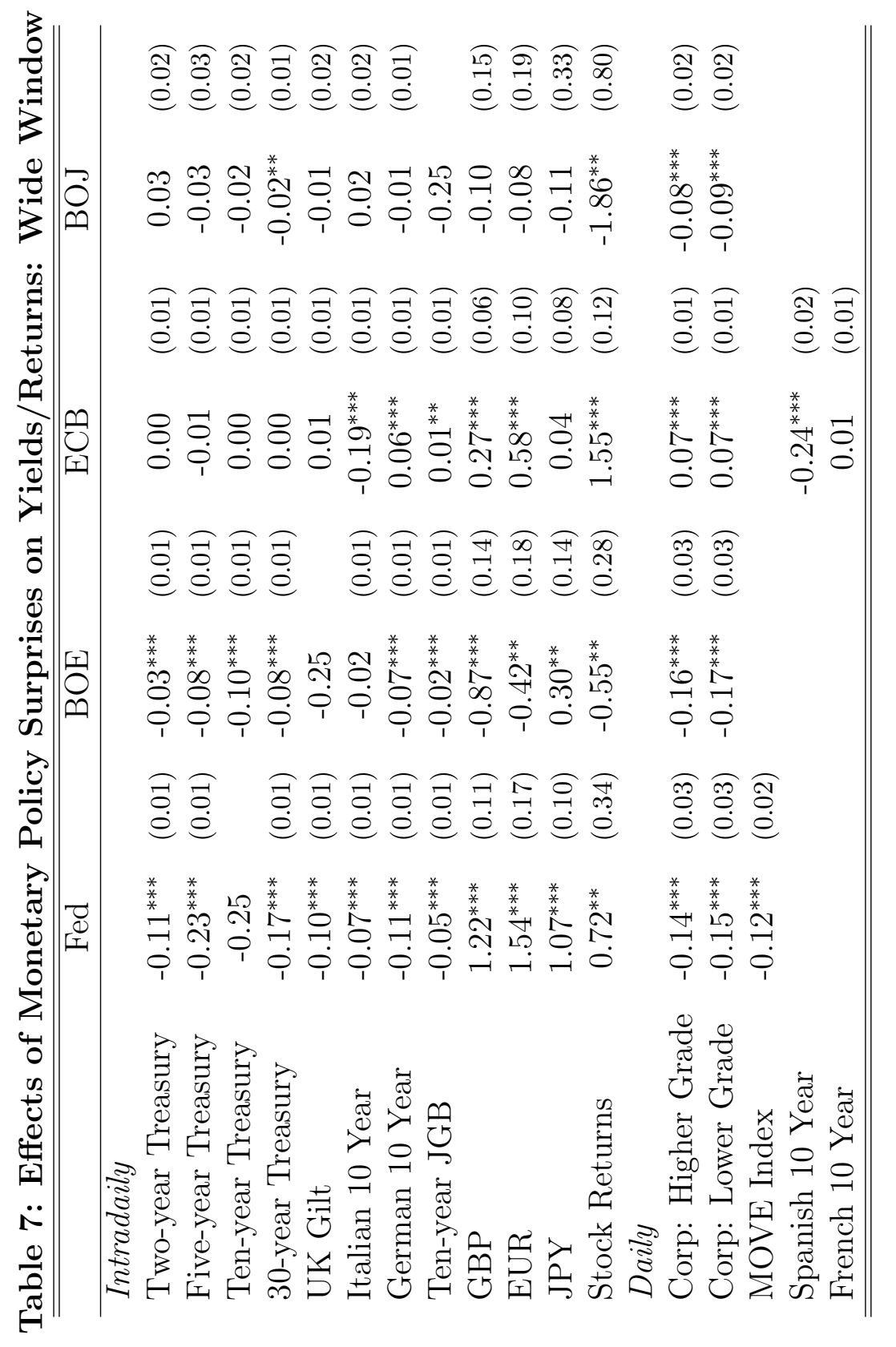

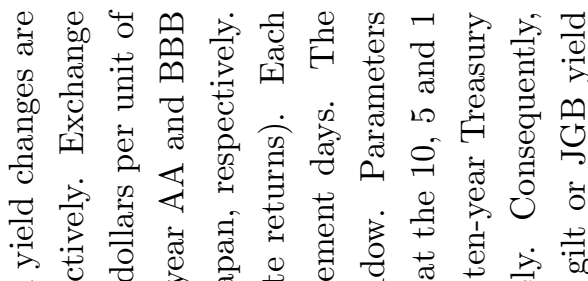

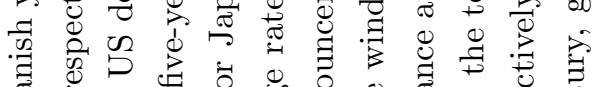

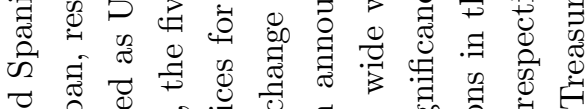
चี

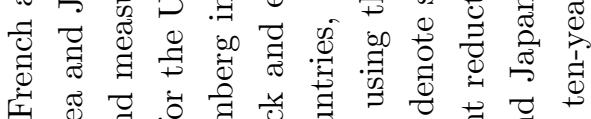

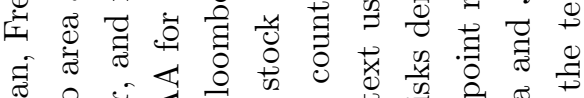

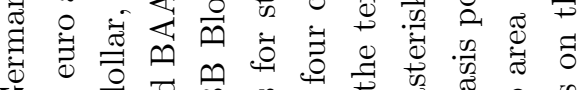

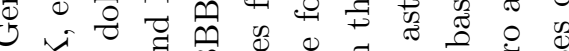

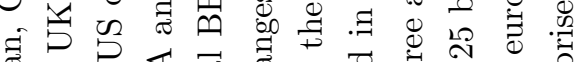

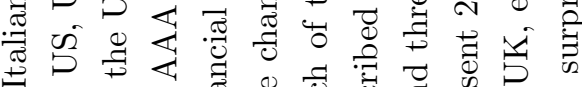

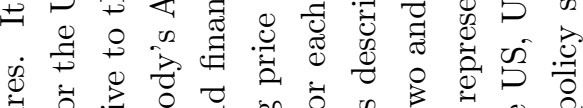

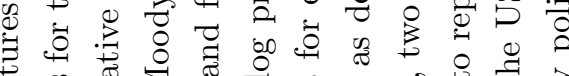
$\exists$ क व

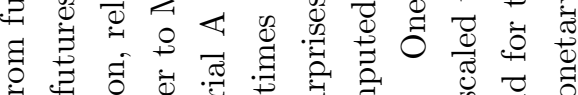

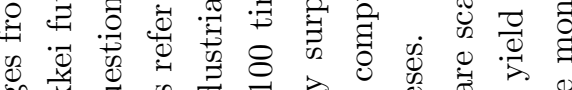

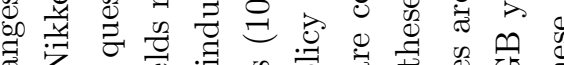

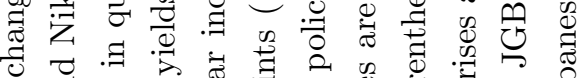
च

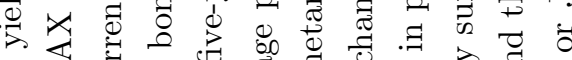

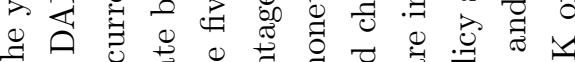

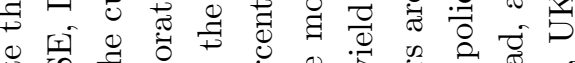

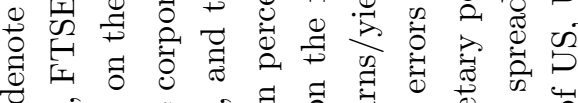
की $\begin{aligned} & 0 \\ & 0\end{aligned}$

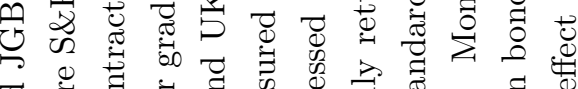
预

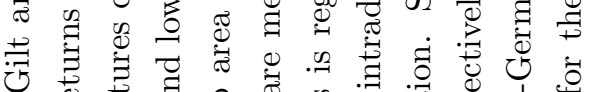
ن

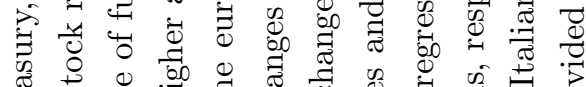

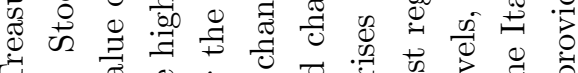

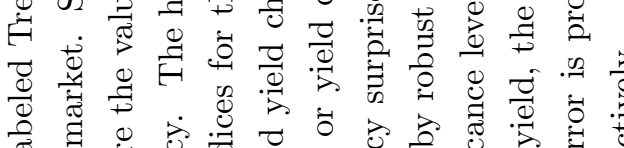

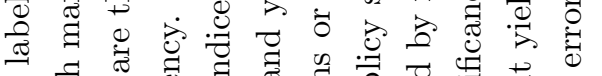

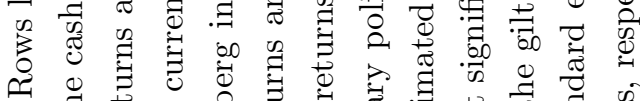
代

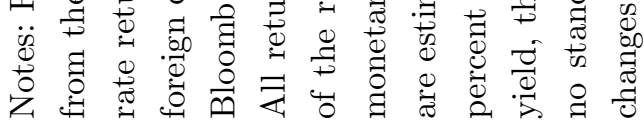




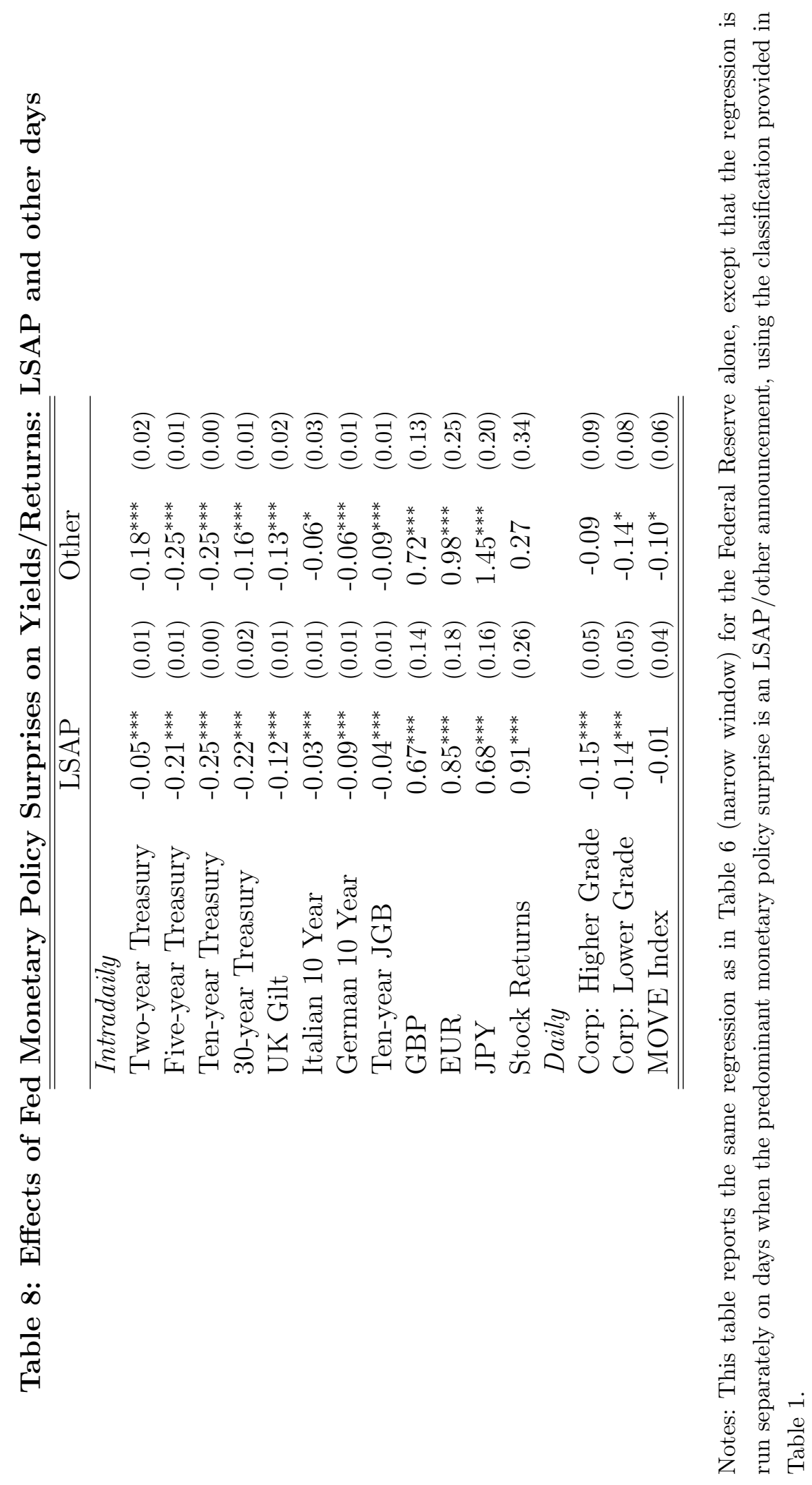




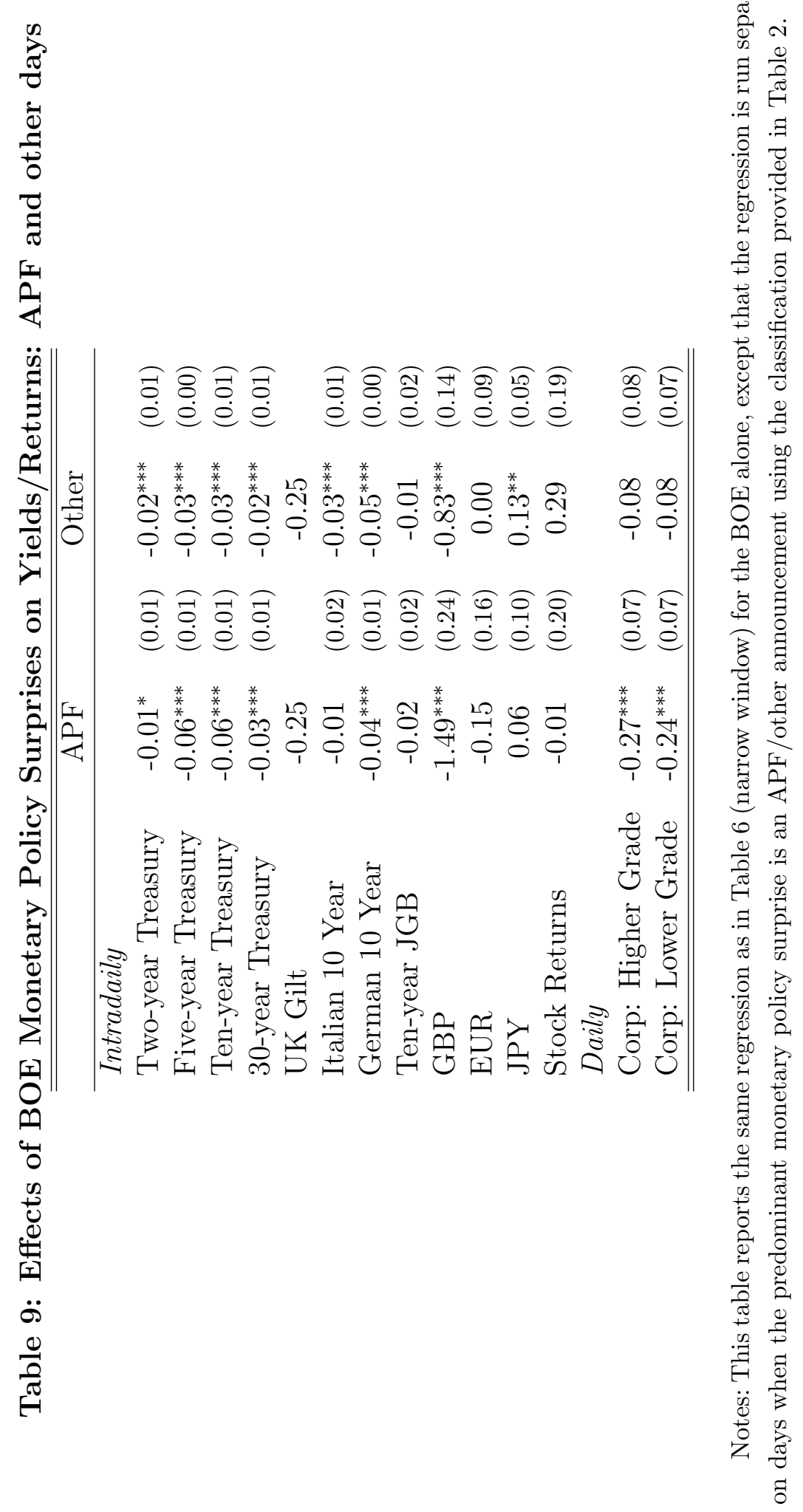




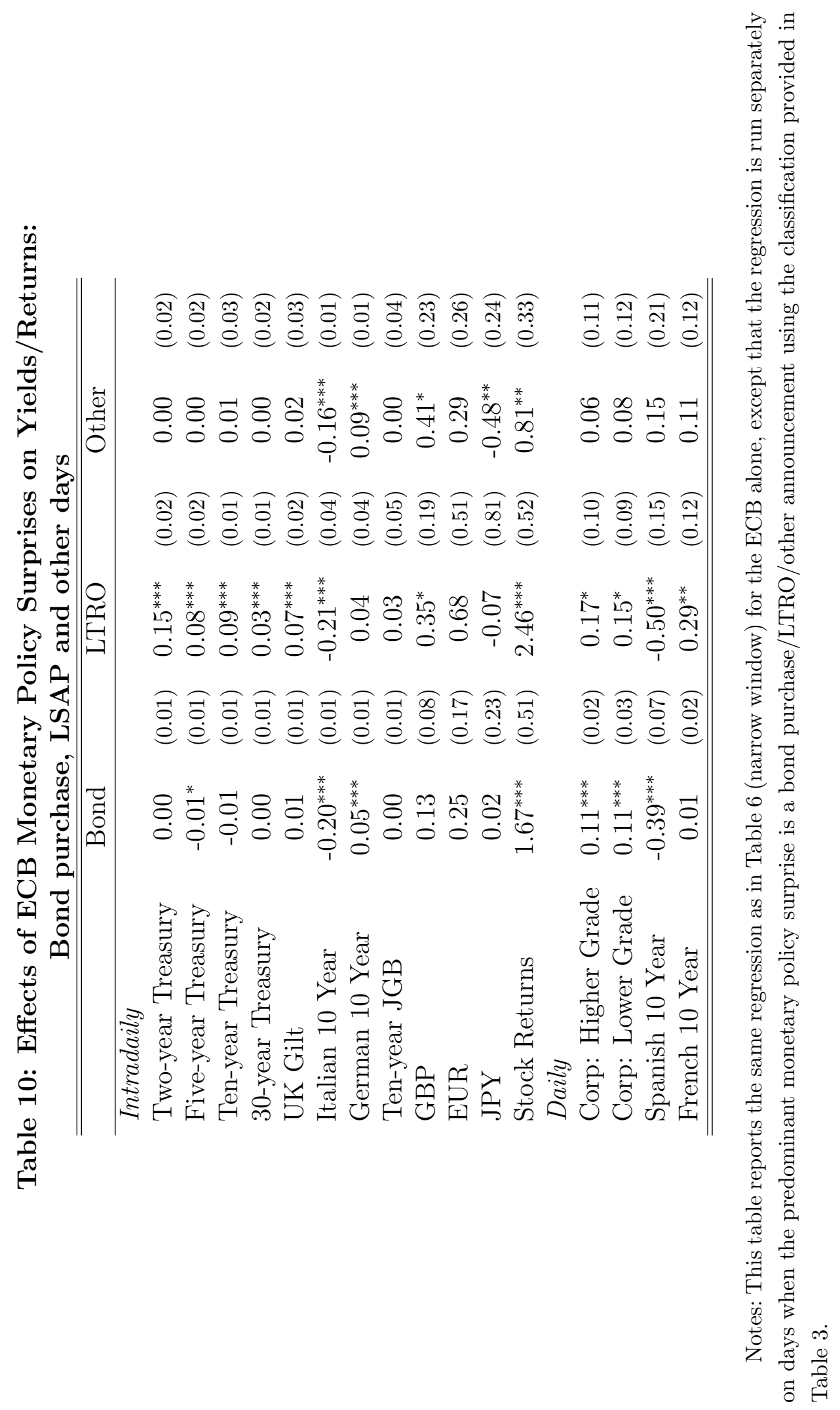




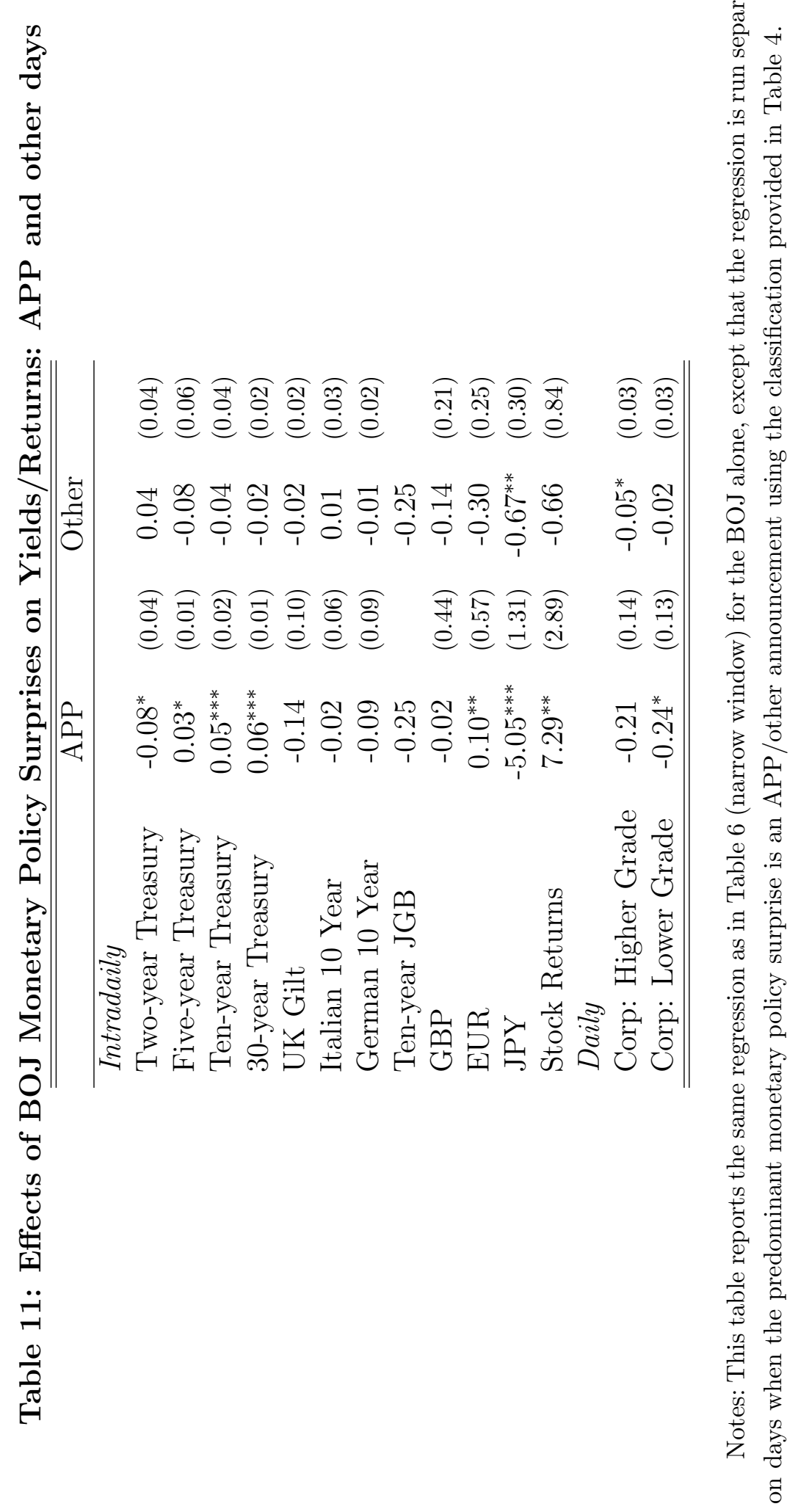




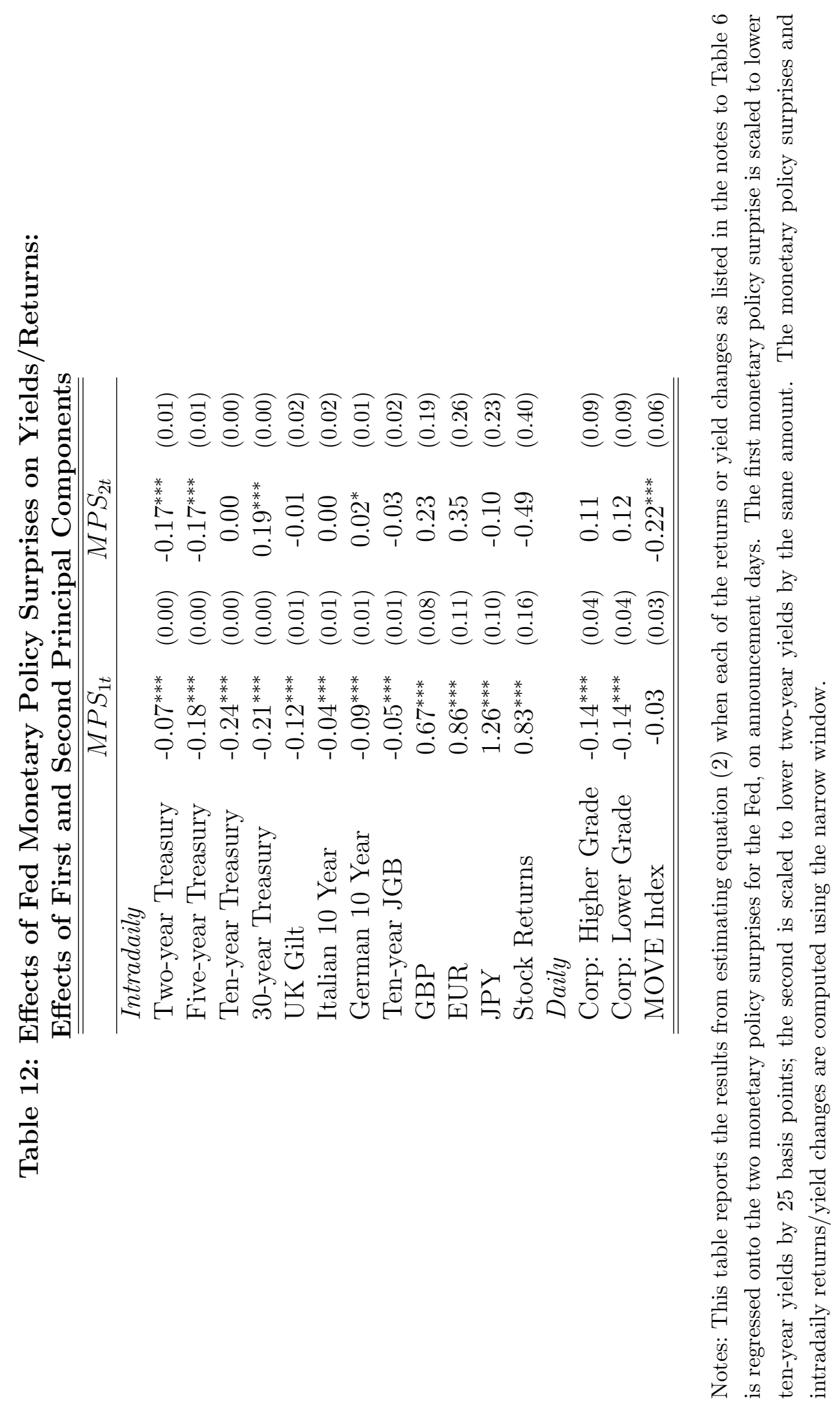




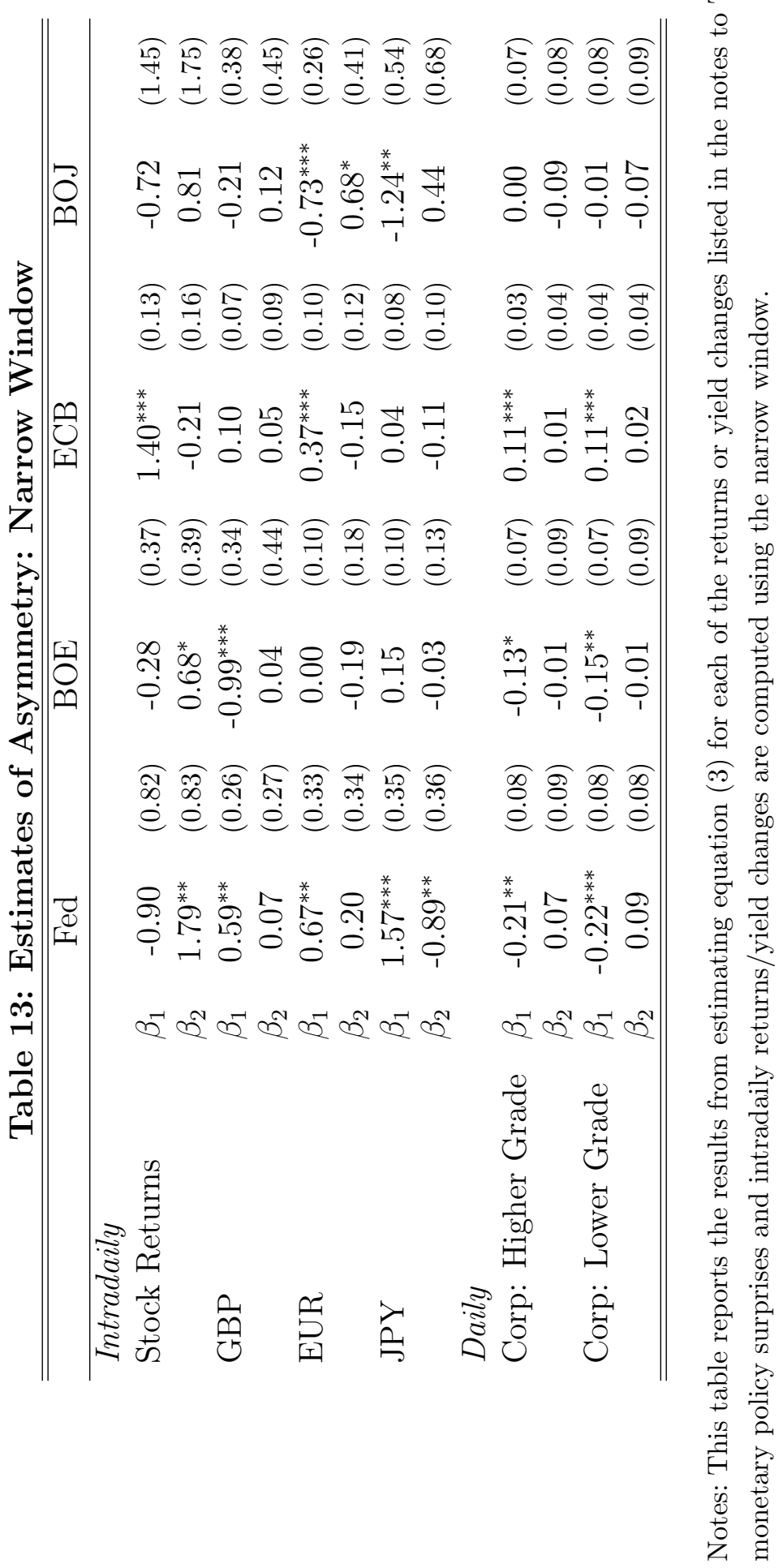




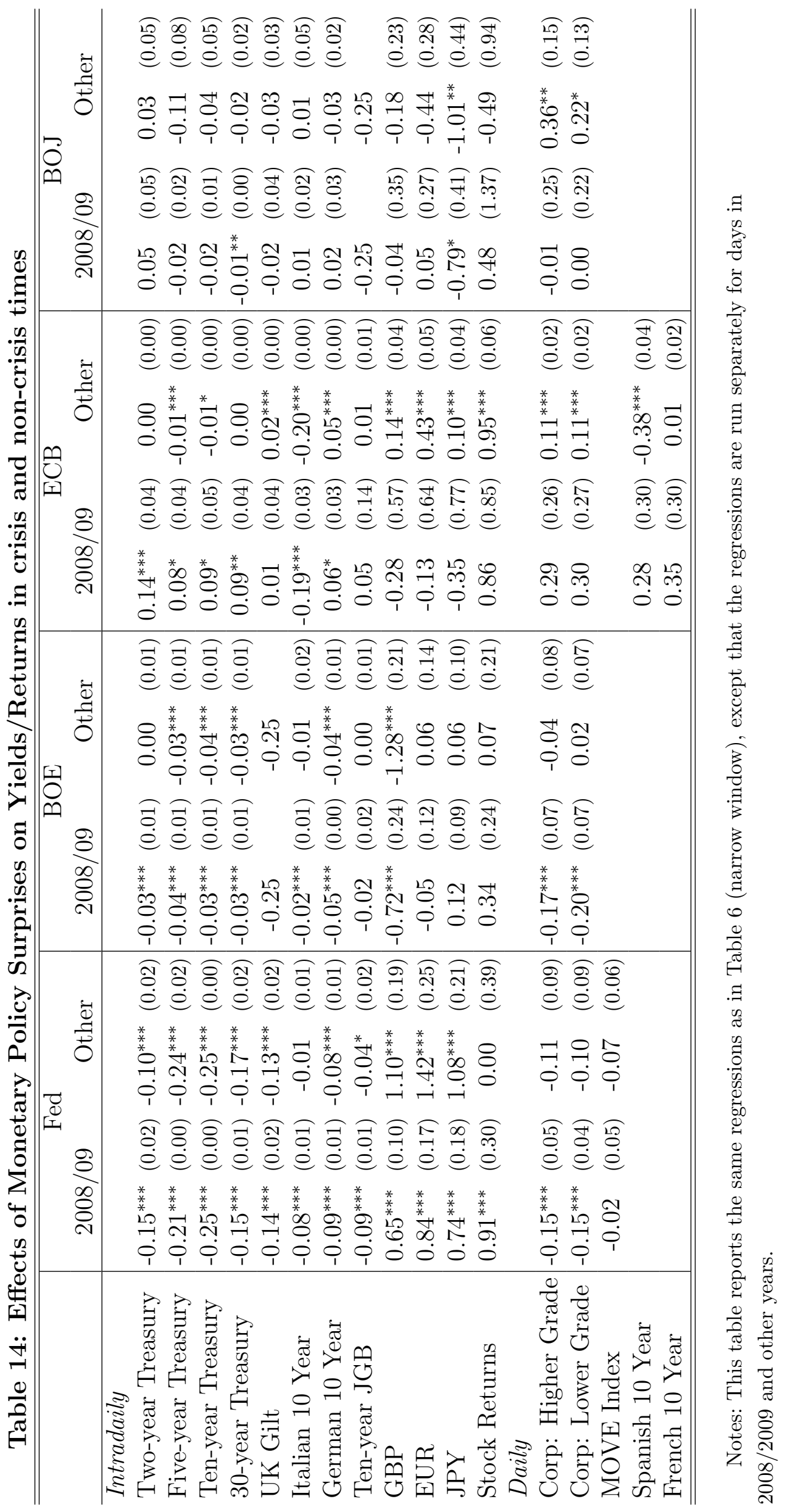




\section{Table 15: Specification Tests}

\begin{tabular}{ccc}
\hline \hline Hypothesis & $\begin{array}{c}\text { Wald Statistic } \\
\text { United States }\end{array}$ & Bootstrap p-value \\
$\Sigma_{0}=\Sigma_{1}$ & 51.1 & 0.002 \\
$\Sigma_{1}-\Sigma_{0}=R_{1} R_{1}^{\prime}$ & 4.7 & 0.768 \\
& United Kingdom \\
$\Sigma_{0}=\Sigma_{1}$ & 25.5 & 0.052 \\
$\Sigma_{1}-\Sigma_{0}=R_{1} R_{1}^{\prime}$ & 6.6 & 0.514 \\
& Euro Area \\
$\Sigma_{0}=\Sigma_{1}$ & 100.6 \\
$\Sigma_{1}-\Sigma_{0}=R_{1} R_{1}^{\prime}$ & 26.9 & 0.000 \\
& Japan & 0.526 \\
$\Sigma_{0}=\Sigma_{1}$ & 4.5 & 0.887 \\
$\Sigma_{1}-\Sigma_{0}=R_{1} R_{1}^{\prime}$ & 2.3 & 0.746 \\
\hline \hline
\end{tabular}

Notes: This table reports the results of specification tests of the hypotheses that the variance-covariance matrix of reduced form errors is the same on announcement and non-announcement days, and that there is a one-dimensional structural shock that characterizes the difference between these two sets of days. Bootstrap $p$-values are included in both cases. The tests and bootstrap methodology are described in Wright (2012). 


\section{Figure 1: Changes in Bond Yields Around Selected Announcements}
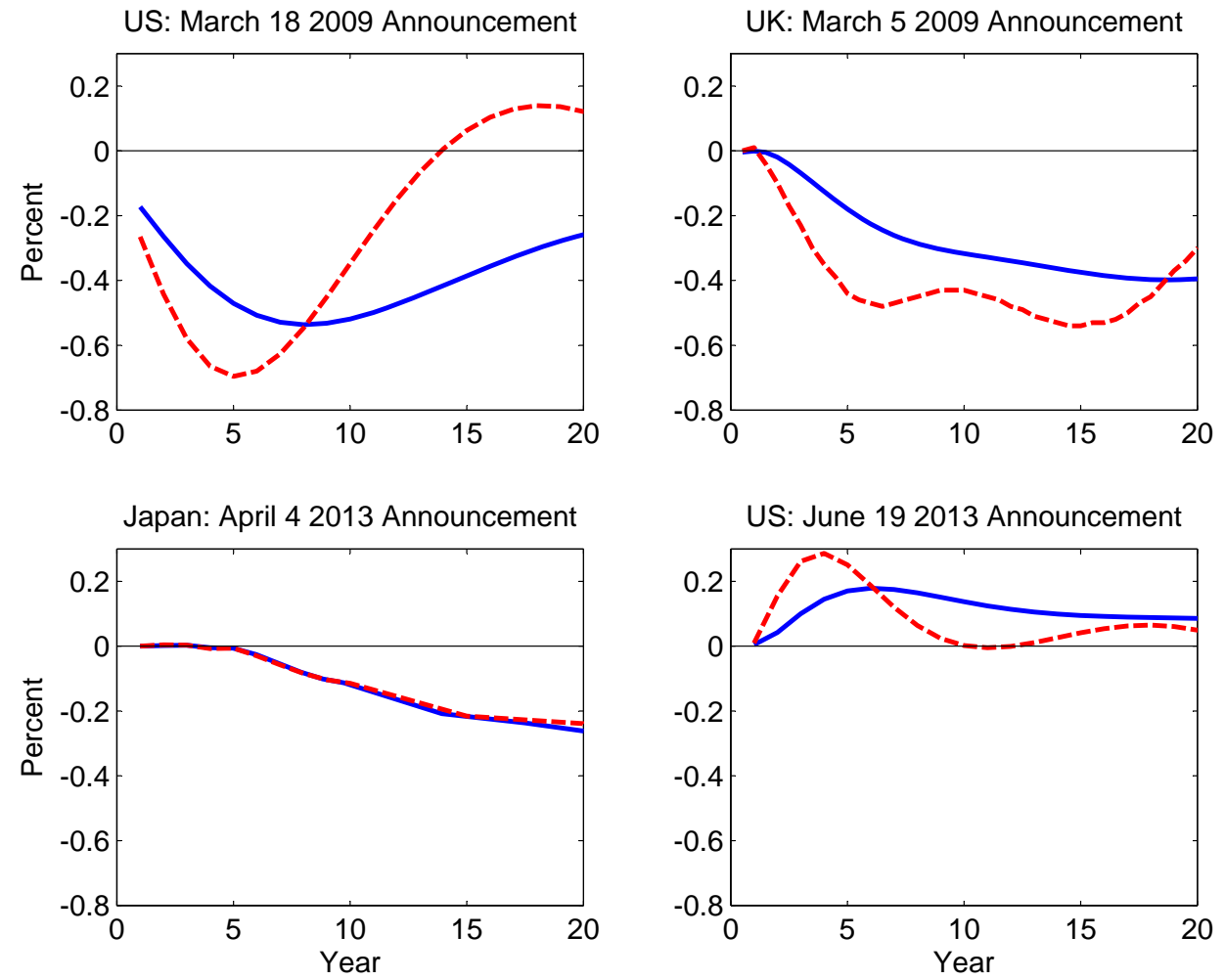

Notes: For four significant monetary policy announcements, this figure plots the change in the zero coupon (blue line) and instantaneous forward (red dashed line) government bond yield curves in that country at the daily frequency from before to after the announcement. 
Figure 2: Federal Reserve Impulse Responses
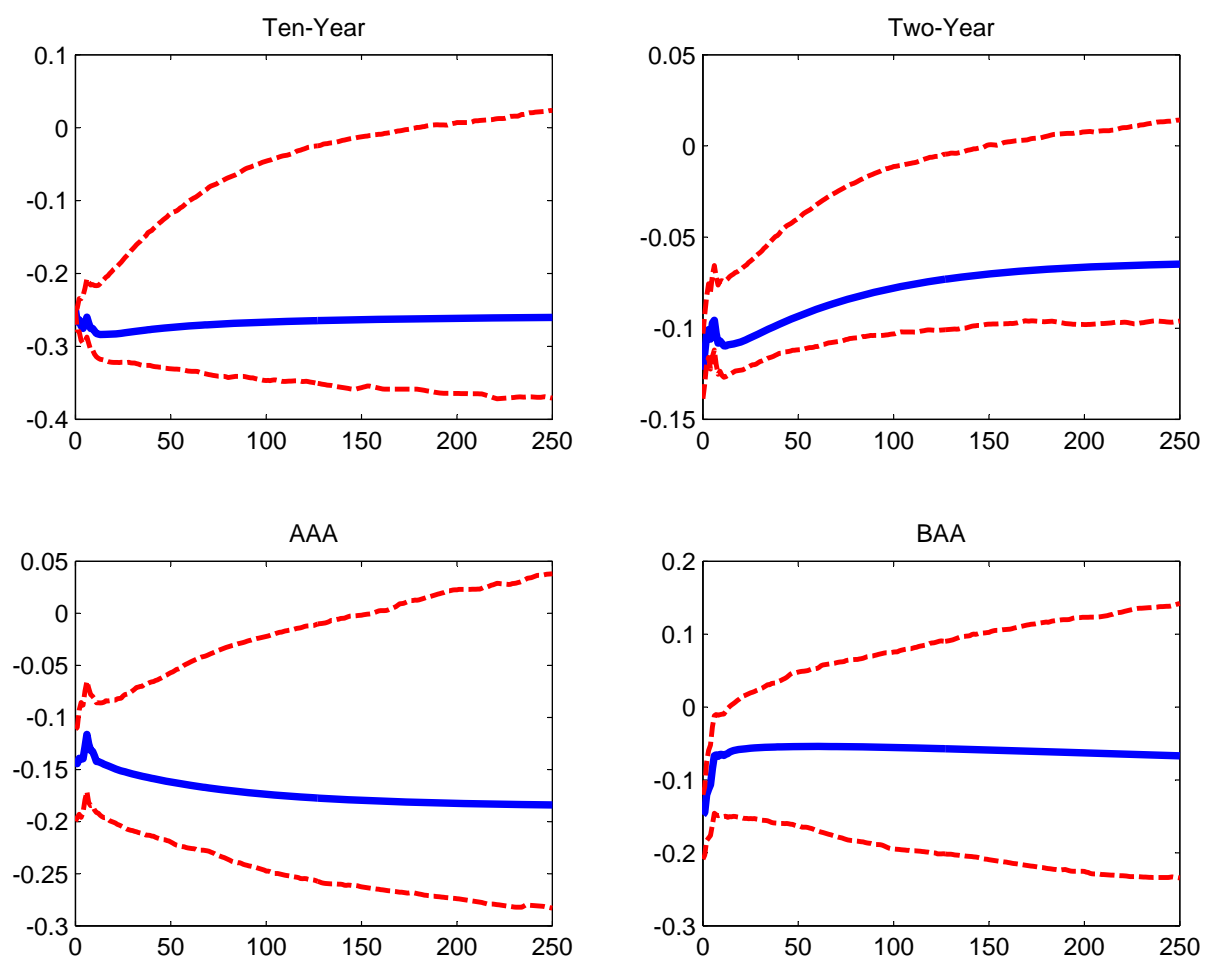

Notes: This figure plots the impulse responses (in days) of a monetary policy surprise consisting of a 25 basis point easing of the ten-year government bond yields in the US, identified as described in section 4 . The specification is a VAR(1) in two- and tenyear government bond yields and corporate yields. 90 percent bootstrap confidence intervals are also shown (dashed lines). 


\section{Figure 3: BOE Impulse Responses}
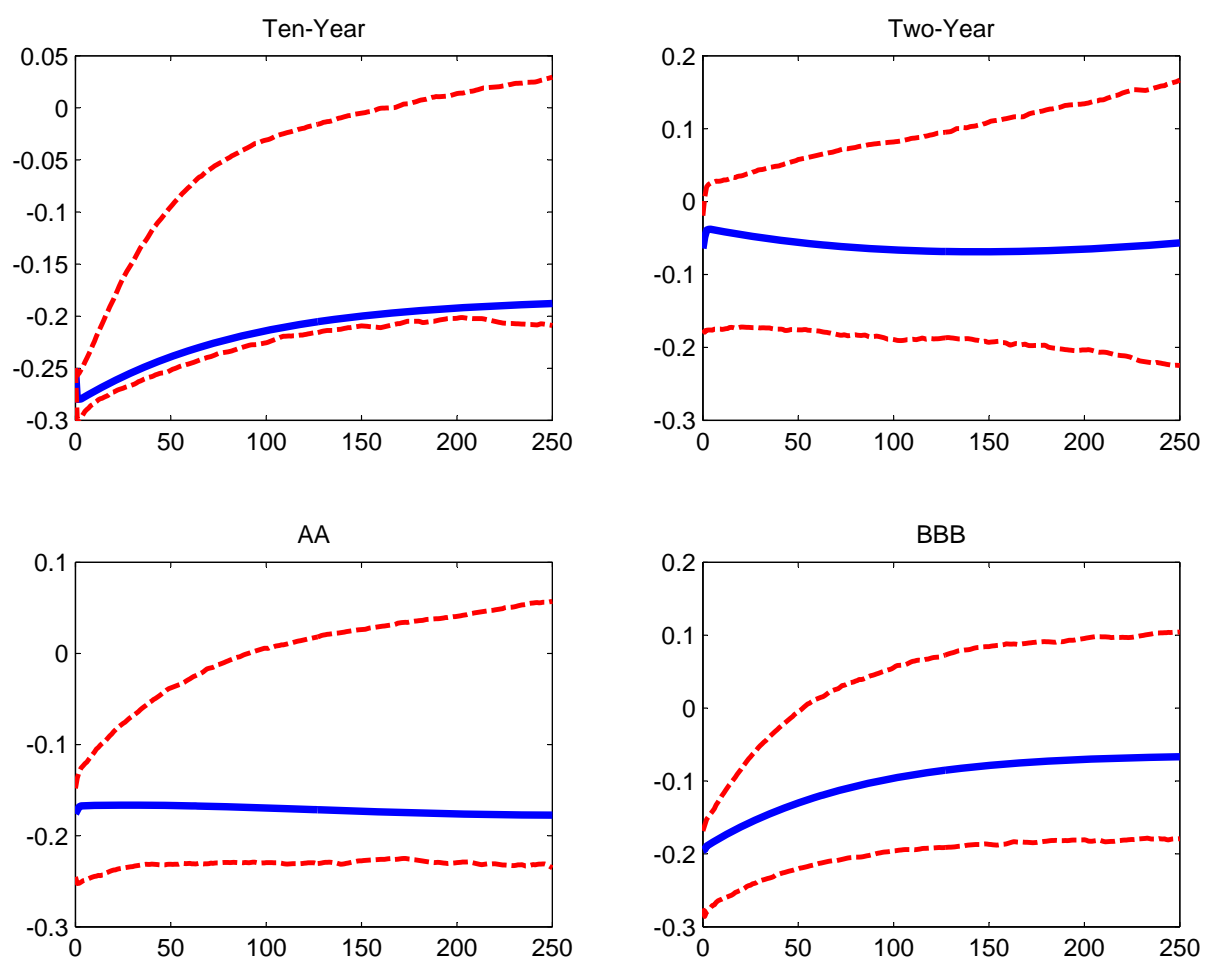

Notes: This figure plots the impulse responses (in days) of a monetary policy surprise consisting of a 25 basis point easing of the ten-year government bond yields in the UK, identified as described in section 4. The specification is a $\operatorname{VAR}(1)$ in two- and tenyear government bond yields and corporate yields. 90 percent bootstrap confidence intervals are also shown (dashed lines). 


\section{Figure 4: ECB Impulse Responses}
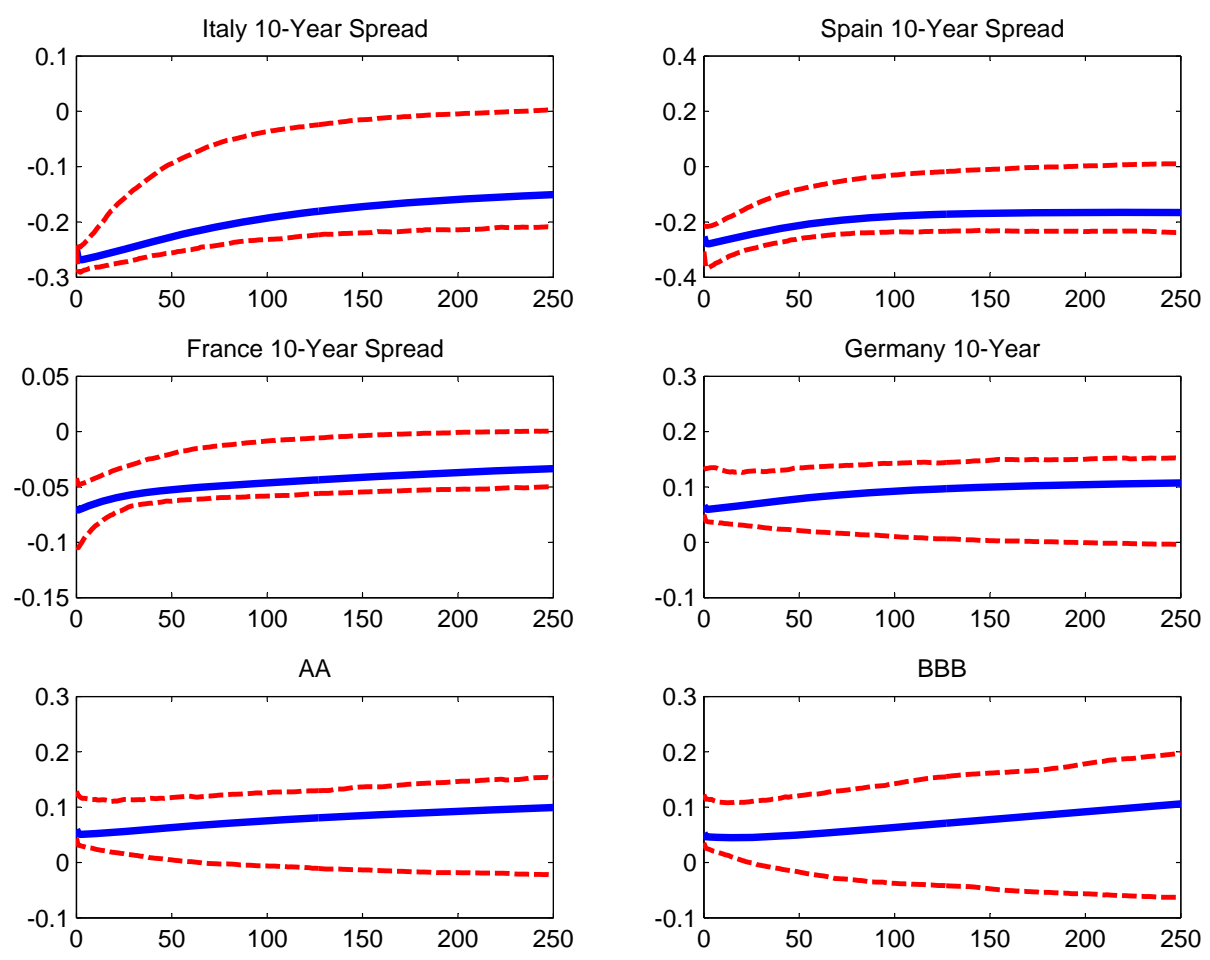

Notes: This figure plots the impulse responses (in days) of a monetary policy surprise consisting of a 25 basis point easing of Italian government bond yields in the euro area, identified as described in section 4. The specification is a VAR(1) in ten-year sovereign spreads, ten-year German yields and corporate yields. 90 percent bootstrap confidence intervals are also shown (dashed lines). 


\section{Figure 5: BoJ Impulse Responses}
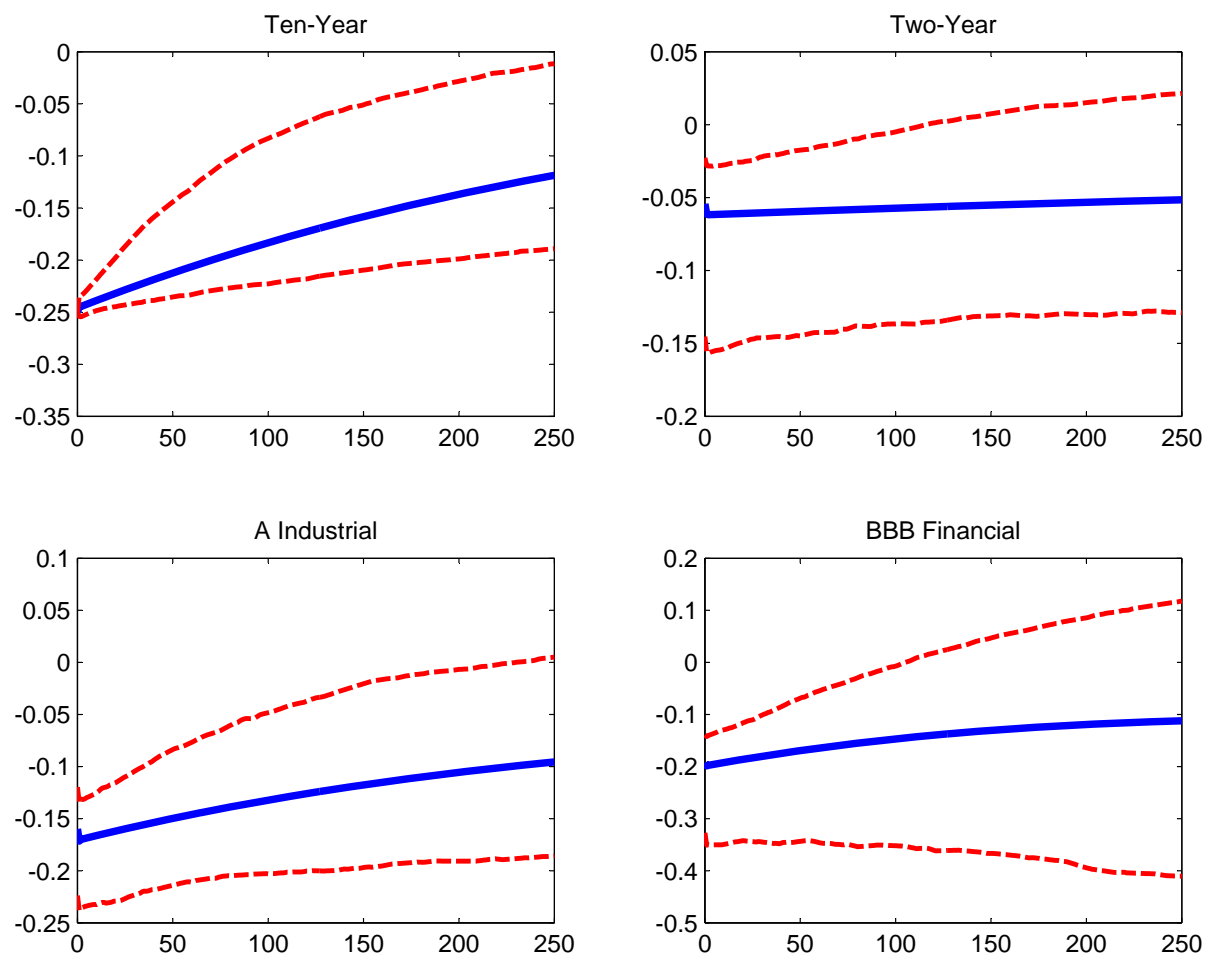

Notes: This figure plots the impulse responses (in days) of a monetary policy surprise consisting of a 25 basis point easing of the ten-year government bond yields in Japan, identified as described in section 4. The specification is a VAR(1) in two- and tenyear government bond yields and corporate yields. 90 percent bootstrap confidence intervals are also shown (dashed lines). 


\section{Figure 6: Federal Reserve Impulse Responses: Identification Through Heteroskedasticity}
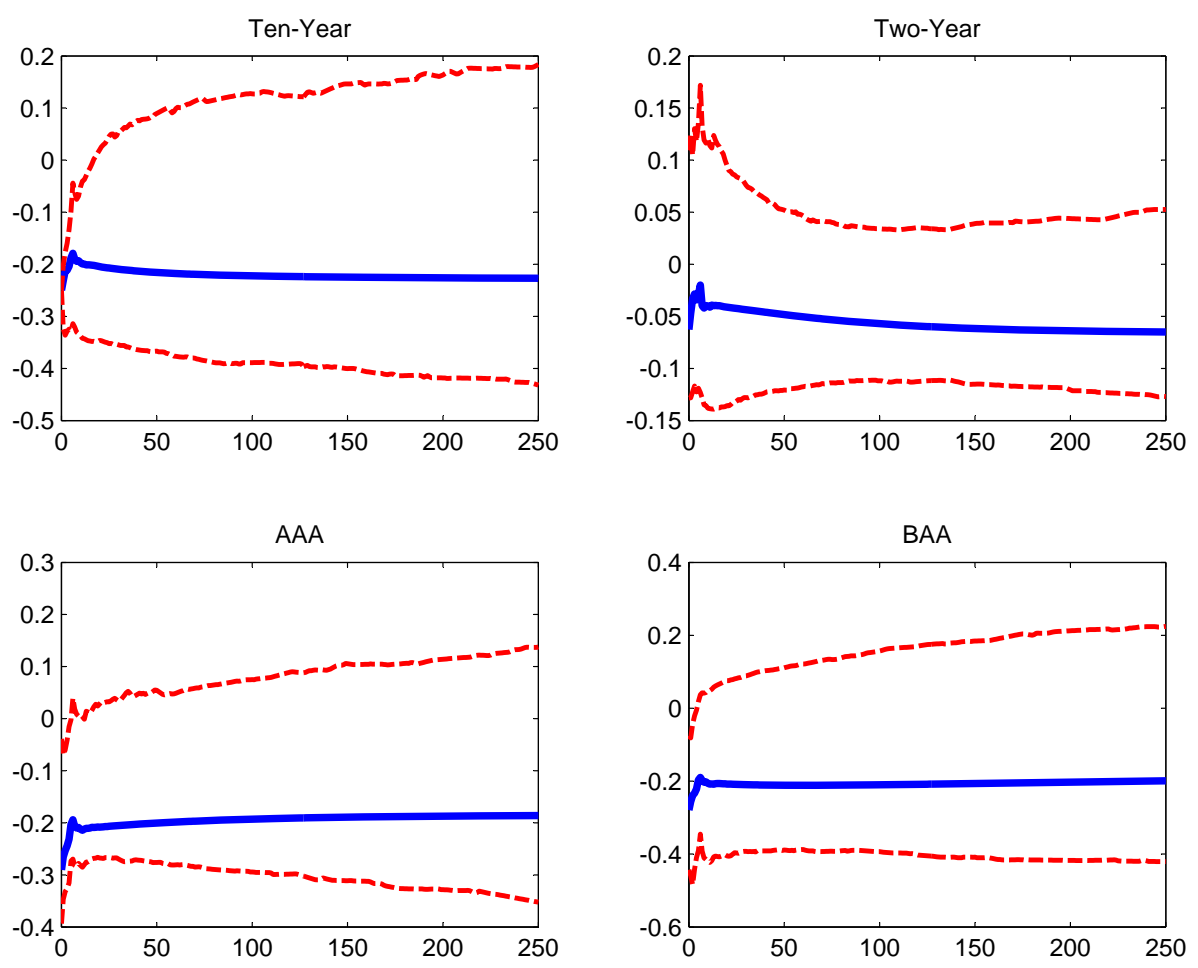

Notes: This figure plots the impulse responses (in days) of a monetary policy surprise consisting of a 25 basis point easing of the ten-year government bond yields in the US, using identification through heteroskedasiticty as described in section 5 . The specification is a VAR(1) in two- and ten-year government bond yields and corporate yields. 90 percent bootstrap confidence intervals are also shown (dashed lines). 


\section{Figure 7: ECB Impulse Responses: Identification Through Heteroskedasticity}
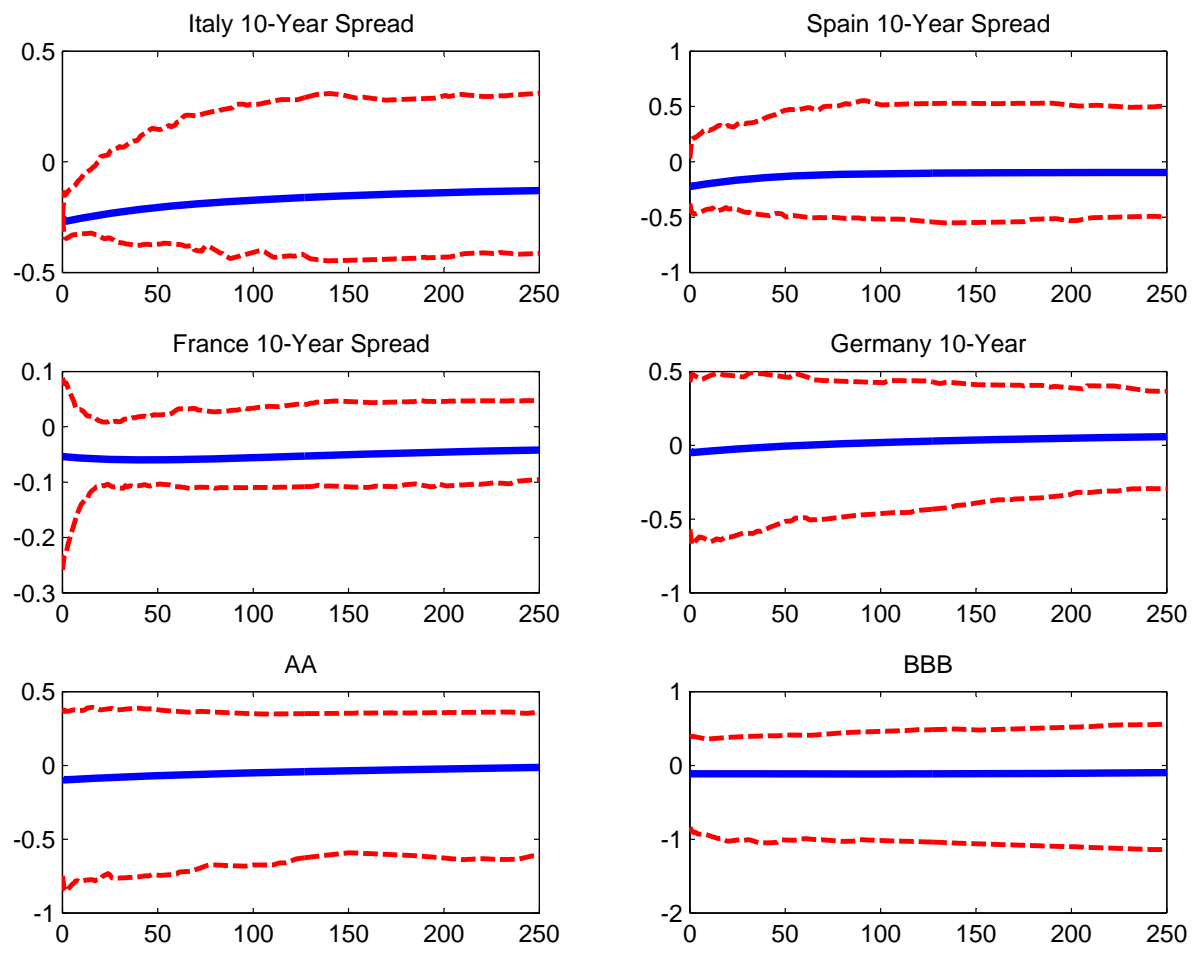

Notes: This figure plots the impulse responses (in days) of a monetary policy surprise consisting of a 25 basis point easing of Italian government bond yields in the euro area, identified, using identification through heteroskedasiticty as described in section 5 . The specification is a $\operatorname{VAR}(1)$ in ten-year sovereign spreads, ten-year German yields and corporate yields. 90 percent bootstrap confidence intervals are also shown (dashed lines). 


\section{References}

Akkaya, Yildiz, "Uncertainty of Interest Rate Path as a Monetary Policy Instrument," 2014. working paper.

Arai, Natsuki, "The Effect of Monetary Policy Announcements at the Zero Lower Bound," 2013. working paper.

Bredin, Don, Stuart Hyde, Dirk Nitzsche, and Gerald O'Reilly, "UK stock returns and the impact of domestic monetary policy shocks," Journal of Business Finance and Accounting, 2007, 34, 872-888.

Cahill, Michael E., Stefania D'Amico, Canlin Li, and John S. Sears, "Duration Risk versus Local Supply Channel in Treasury Yields: Evidence from the Federal Reserve's Asset Purchase Announcements," 2013. Finance and Economics Discussion Series, 2013-35.

Cenesizoglu, Tolga and Badye O. Essid, "The Effect of Monetary Policy on Credit Spreads," Journal of Financial Research, 2012, 35, 581-613.

D'Amico, Stefania and Thomas B. King, "Flow and Stock Effects of Large-Scale Treasury Purchases," Journal of Financial Economics, 2013, 108, 425-448.

_, William English, David López-Salido, and Edward Nelson, "The Federal Reserve's Large-Scale Asset Purchase Programmes: Rationale and Effects," Economic Journal, 2012, 122, 415-446.

Doh, Taeyoung, "The Efficacy of Large-Scale Asset Purchases at the Zero Lower Bound," Federal Reserve Bank of Kansas City Economic Review, 2010, 2, 5-34.

Duffie, Darrell, "Asset Price Dynamics with Slow-Moving Capital," Journal of Finance, 2010, 65, 1238-1268.

Eggertsson, Gauti and Michael Woodford, "The Zero Lower Bound on Interest Rates and Optimal Monetary Policy," Brookings Papers on Economic Activity, 2003, 1, 139-211.

Ehrmann, Michael and Marcel Fratzscher, "Equal Size, Equal Role? Interest Rate Interdependence between the Euro Area and the United States," Economic Journal, 2005, 115, 930-950.

Fama, Eugene, Kenneth French, Michael Jensen, and Richard Roll, "The Adjustment of Stock Prices to New Information," International Economic Review, $1969,10,1-21$.

Faust, Jon, John H. Rogers, Shing-Yi B. Wang, and Jonathan H. Wright, "The High-Frequency Response of Exchange Rates and Interest Rates to Macroeconomic Announcements," Journal of Monetary Economics, 2007, 54, 1051-1068.

Fratzscher, Marcel, Marco Lo Duca, and Roland Straub, "On the International Spillovers of US Quantitative Easing," 2013. ECB working paper 1557. 
Gagnon, Joseph, Matthew Raskin, Julie Remache, and Brian Sack, "LargeScale Asset Purchases by the Federal Reserve: Did They Work?," International Journal of Central Banking, 2011, 7, 3-44.

Ghysels, Eric, Julien Idier, Simone Manganelli, and Olivier Vergote, "A high frequency assessment of the ECB Securities Markets Programme," 2012. working paper.

Giannone, Domenico, Michele Lenza, Huw Pill, and Lucrezia Reichlin, "Non-standard monetary policy measures and monetary developments," in Jagjit S. Chadha and Sean Holly, eds., Interest Rates, Prices and Liquidity-Lessons from the Financial Crisis, Cambridge University Press 2011.

Gilchrist, Simon and Egon Zakrajsek, "The Impact of the Federal Reserve's Large-Scale Asset Purchase Program on Corporate Credit Risk," 2013. NBER Working Paper 19337.

_ , David López-Salido, and Egon Zakrajsek, "Monetary Policy and Real Borrowing Costs at the ZLB," 2013. working paper.

Glick, Reuven and Sylvain Leduc, "Central Bank Announcements of Asset Purchases and the Impact on Global Financial and Commodity Markets," Journal of International Money and Finance, 2012, 31, 2078-2101.

_ and _ , "The Effects of Unconventional and Conventional U.S. Monetary Policy on the Dollar," 2013. Federal Reserve Bank of San Francisco working paper 2013-11.

Greenwood, Robin and Dimitri Vayanos, "Bond Supply and Excess Bond Returns," Review of Financial Studies, forthcoming.

Gürkaynak, Refet S. and Jonathan H. Wright, "Market-Based Measures of International Monetary Policy Dependence," 2011. working paper.

_ and _ " "Identification and Inference Using Event Studies," The Manchester School, 2013, 81, 48-65.

_ , Brian Sack, and Eric T. Swanson, "The Sensitivity of Long-Term Interest Rates to Economic News: Evidence and Implications for Macroeconomic Models," American Economic Review, 2005a, 95, 425-436.

_, _, and _, "Do Actions Speak Louder Than Words? The Response of Asset Prices to Monetary Policy Actions and Statements," International Journal of Central Banking, 2005b, 1, 55-93.

Hamilton, James D. and Jing Cynthia Wu, "The Effectiveness of Alternative Monetary Policy Tools in a Zero Lower Bound Environment," Journal of Money Credit and Banking, 2012, 44, 3-46.

Huber, Peter J., Robust Statistics, Hoboken, New Jersey: John Wiley and Sons, 1981.

IMF, "Unconventional Monetary Policies-Recent Experience and Prospects," 2013. Background paper. 
Jeanne, Olivier, "Fiscal Challenges to Monetary Dominance in the Euro Area: A Theoretical Perspective," Banque de France Financial Stability Review, 2012, 16, $143-150$.

Joyce, Michael A.S., Ana Lasaosa, Ibrahim Stevens, and Matthew Tong, "The Financial Market Impact of Quantitative Easing in the United Kingdom," International Journal of Central Banking, 2011, 7, 113-161.

- and Matthew Tong, "QE and the Gilt Market: a Disaggregated Analysis," Economic Journal, 2012, 122, 348-384.

Kiley, Michael T., "The Response of Equity Prices to Movements in Long-term Interest Rates Associated With Monetary Policy Statements: Before and After the Zero Lower Bound," 2013a. Finance and Economics Discussion Series, 2013-15.

_, "Monetary Policy Statements, Treasury Yields, and Private Yields: Before and After the Zero Lower Bound," 2013b. Finance and Economics Discussion Series, 2013-16.

Kilian, Lutz, "Small-sample confidence intervals for impulse response functions," Review of Economics and Statistics, 1998, 80, 218-230.

Krishnamurthy, Arvind and Annette Vissing-Jorgenson, "The Effects of Quantitative Easing on Long-term Interest Rates," Brookings Papers on Economic Activity, 2011, 2, 215-265.

_ and _, "The Ins and Outs of LSAPs," Federal Reserve Bank of Kansas City Economic Policy Symposium, 2013.

Kuttner, Kenneth, "Monetary Policy Surprises and Interest Rates: Evidence from the Fed Funds Futures Market," Journal of Monetary Economics, 2001, 47, 523544 .

Lenza, Michele, Huw Pill, and Lucrezia Reichlin, "Monetary Policy in Exceptional Times," Economic Policy, 2010, 25, 295-339.

Li, Canlin and Min Wei, "Term Structure Modeling with Supply Factors and the Federal Reserve's Large-Scale Asset Purchase Programs," International Journal of Central Banking, 2013, 9, 3-39.

Lou, Dong, Hongjun Yan, and Jinfan Zhang, "Anticipated and Repeated Shocks in Liquid Markets," Review of Financial Studies, 2013, 26, 1891-1912.

Meaning, Jack and Feng Zhu, "The Impact of Recent Central Bank Asset Purchase Programmes," BIS Quarterly Review, 2011, pp. 73-83.

Mitchell, Mark, Lasse H. Pedersen, and Todd Pulvino, "Slow Moving Capital," American Economic Review, 2007, 97, 215-220.

Modigliani, Franco and Richard Sutch, "Innovations in Interest Rate Policy," American Economic Review, 1966, 52, 178-197. 
_ and _ , "Debt Management and the Term Structure of Interest Rates: An Empirical Analysis of Recent Experience," Journal of Political Economy, 1967, 75, 569-589.

Neely, Christopher, "The Large-Scale Asset Purchases Had Large International Effects," 2010. Federal Reserve Bank of Saint Louis working paper 2010-18A.

Piazzesi, Monika and Eric T. Swanson, "Futures Prices as Risk-Adjusted Forecasts of Monetary Policy," Journal of Monetary Economics, 2008, 55, 677-691.

Raskin, Matthew, "The Effects of Monetary Policy on Corporate Bond Yields," 2013. working paper.

Rigobon, Roberto and Brian Sack, "Identification through heteroskedasticity," Review of Economics and Statistics, 2003a, 85, 777-792.

_ and _ , "Measuring the response of monetary policy to the stock market," Quarterly Journal of Economics, 2003b, 118, 639-669.

_ and _, "The impact of monetary policy on asset prices," Journal of Monetary Economics, 2004, 51, 1553-1575.

_ and _, "The effects of war risk on US financial markets," Journal of Banking and Finance, 2005, 29, 1769-1789.

Rosa, Carlos, "How "Unconventional" Are Large-Scale Asset Purchases? The Impact of Monetary Policy on Asset Prices," 2012. Federal Reserve Bank of New York Staff Reports, 560.

Stein, Jeremy C., "Evaluating Large-Scale Asset Purchases," 2012. Speech delivered at the Brookings Institution, Washington, October 112012.

Swanson, Eric T., "Let's Twist Again: A High-Frequency Event-Study Analysis of Operation Twist and Its Implications for QE2," Brookings Papers on Economic Activity, 2011, 1, 151-188.

Vayanos, Dimitri and Jean-Luc Vila, "A Preferred-Habitat Model of the Term Structure of Interest Rates," 2009. Working paper.

Williams, John C. and David Reifschneider, "Three Lessons for Monetary Policy in a Low Inflation Era," Journal of Money Credit and Banking, 2000, 32, 936-966.

Wright, Jonathan H., "What Does Monetary Policy do at the Zero Lower Bound?," Economic Journal, 2012, 122, 447-466. 